\title{
FB Line Basis for Interim Operation
}

by

B. Shedrow

Westinghouse Savannah River Company

Savannah River Site

Aiken, South Carolina 29808

\section{RECEIVED \\ NOV 051998 \\ OST.I}

This paper was prepared in connection with work done under the above contract number with the U.S. Department of Energy. By acceptance of this paper, the publisher and/or recipient acknowledges the U.S. Government's right to retain a nonexclusive, royalty-free license in and to any copyright covering this paper, along with the right to reproduce and to authorize others to reproduce all or part of the copyrighted paper. 


\section{DISCLAIMER}

This report was prepared as an account of work sponsored by an agency of the United States Government. Neither the United States Government nor any agency thereof, nor any of their employees, makes any warranty, express or implied, or assumes any legal liability or responsibility for the accuracy, completeness, or usefulness of any information, apparatus, product, or process disclosed, or represents that its use would not infringe privately owned rights. Reference herein to any specific commercial product, process, or service by trade name, trademark, manufacturer, or otherwise does not necessarily constitute or imply its endorsement, recommendation, or favoring by the United States Government or any agency thereof. The views and opinions of authors expressed herein do.not necessarily state or reflect those of the United States Government or any agency thereof.

This report has been reproduced directly from the best available copy.

Available to DOE and DOE contractors from the Office of Scientific and Technical Information, P. O. Box 62, Oak Ridge, TN 37831; prices available from (423) 576-8401.

Available to the public from the National Technical Information Service, U. S. Department of Commerce, 5285. Port Royal Road, Springfield, VA 22161. 


\section{DISCLAIMER}

Portions of this document may be illegible in electronic image products. Images are produced from the best available original document. 


\section{DELETED , VERSION}

Engineering and Projects Division Safety Services Section

\section{INFORMATION ONLY}

FB LINE Basis for Interim Operation (U)

THCUSSFIED ooss not contain MOASSAFEO CONTROLLED MIE SNR IMFORAATION Holouplase z/16 18

T. R Chughtivour CUSSIFCLTION ANALYSY

H. S. Smiley
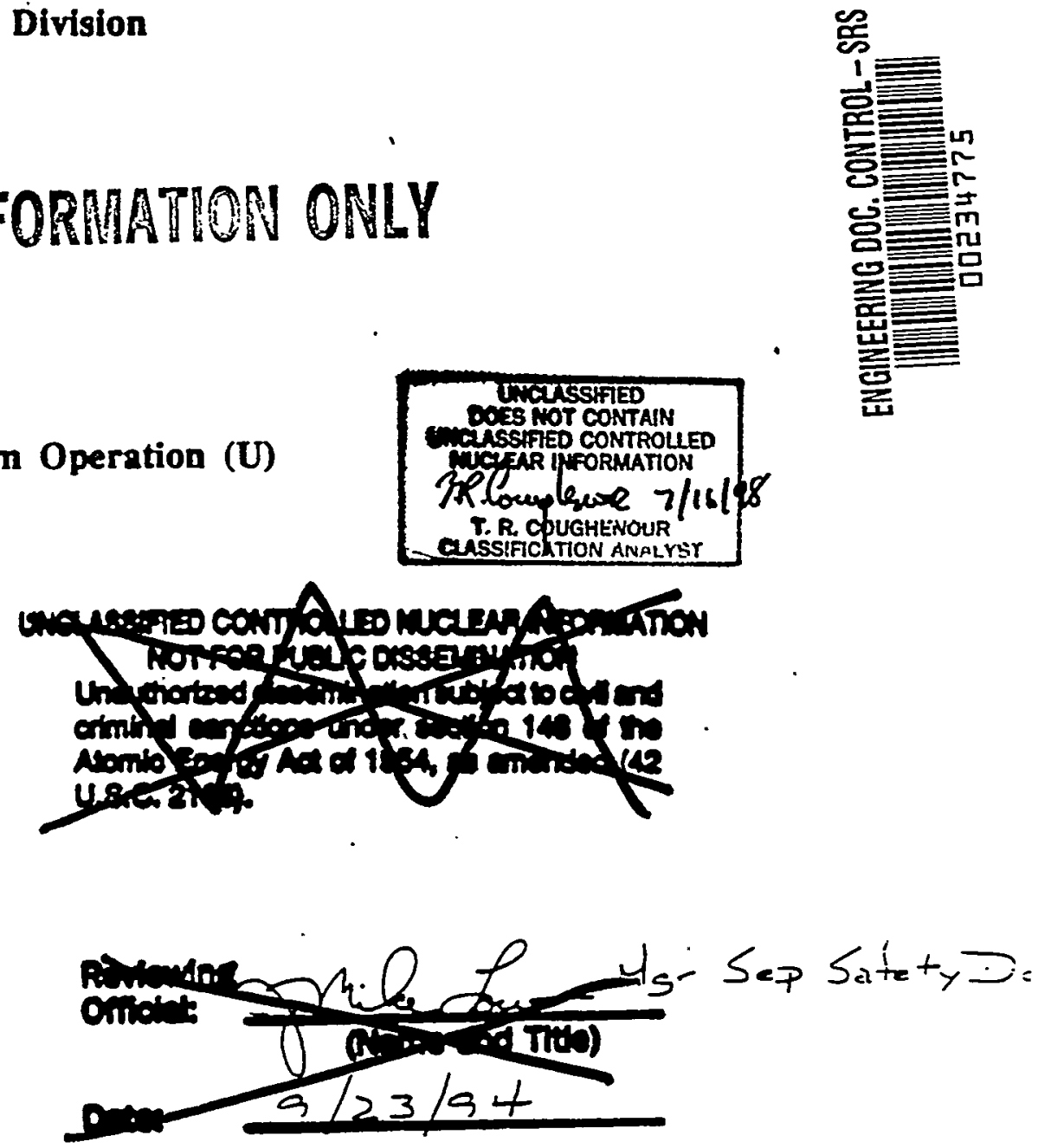

September 1994
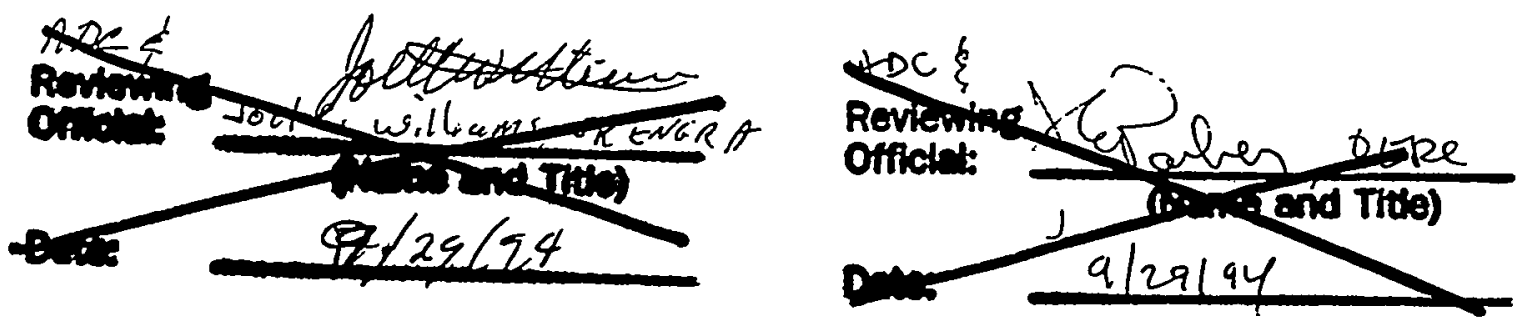
Table of Contents

EXECUTIVE SUMMARY. 4

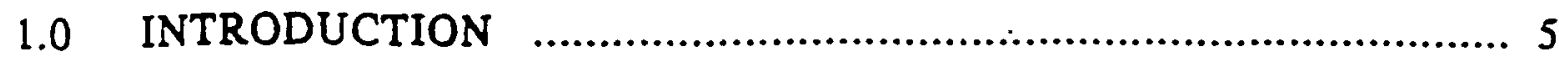

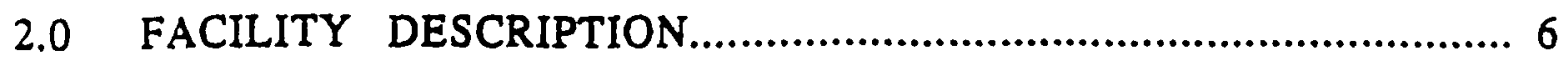

2.1 Cation Exchange............................................................ 6

2.2 Precipitation and Filtration....................................................... 6

2.3 Mechanical Line.............................................................. 6

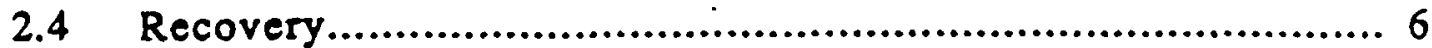

2.5 Special Recovery.............................................................. 7

3.0 RELEVANT OPERATIONAL HISTORY......................................... 7

3.1 Significant Events............................................................... 7

3.2 Significant Equipment/Operations Changes/Upgrades........................... 8

4.0 SAFETY DOCUMENTATION..................................................... 9

4.1 Authorization Basis Documents................................................... 10

4.2 Other Documents.............................................................. 14

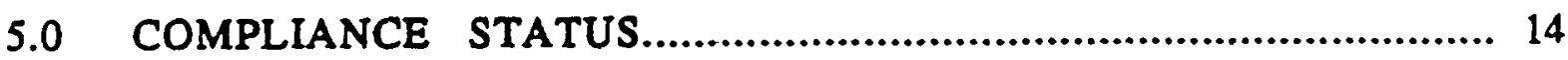

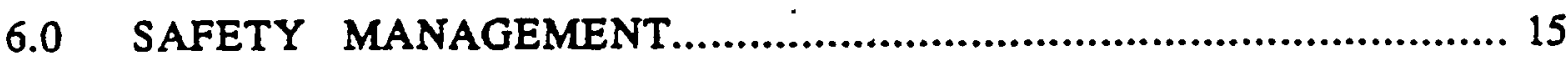

6.1 Managoright Policies.......................................................... 16

6.2 Management Responsibilities.................................................... 16

6.3 System of Control Documents................................................... 18

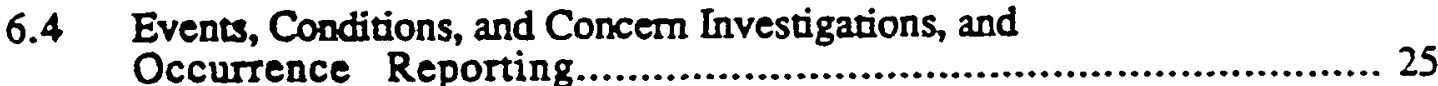

6.5 Review and Audit............................................................ 25

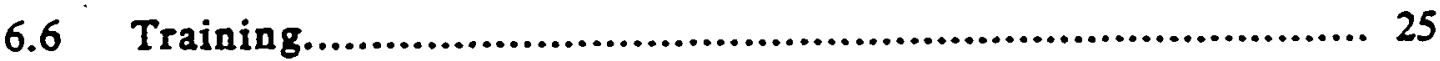

6.7 Facility Operating Records....................................................... 26

6.8 Radiation Protection Program.................................................... 27

6.9 Facility Radioactive and Hazardous Materials Shipping and Receiving Program. 
Table of Contents (continued)

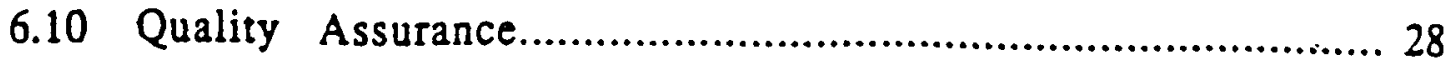

6.11 Waste Management........................................................... 28

6.12 Equipment Maintenance........................................................ 28

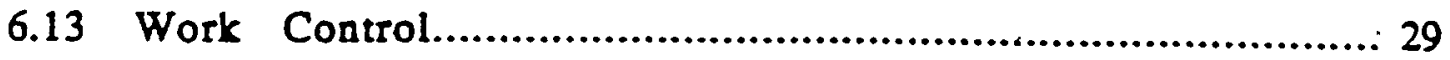

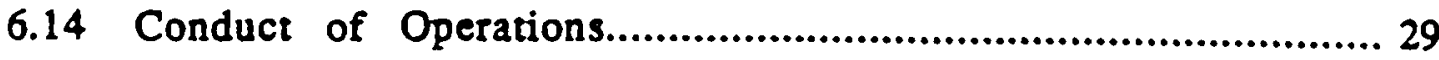

6.15 Performance Indicators........................................................... 30

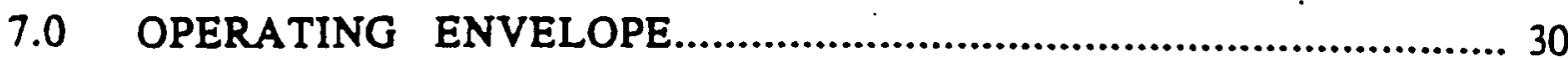

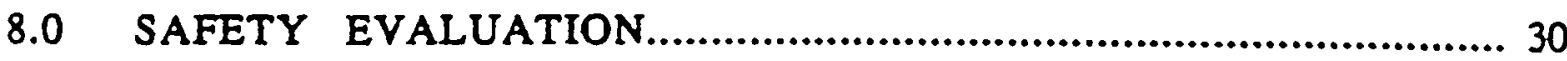

8.1 Facility Categorization and Hazard Identification................................ 30

8.2 Hazard Analysis and Accident Categorization.................................. 33

8.3 Accident Analysis................................................................ 38

8.4 Farmer Plots............................................................... 58

8.5 Safety-Related Description Approach.............................................. 61

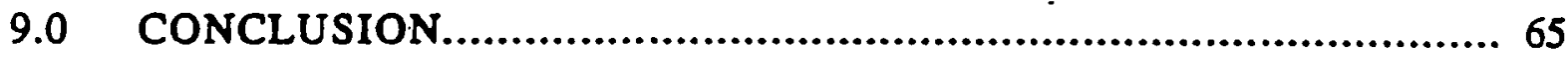

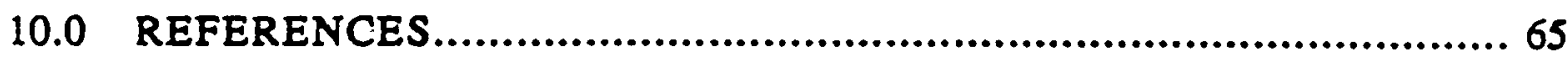

\section{List of Tables}

4.A fiplicwille Authorization Basis Documents

4.B List of Non-Applicable Sections from the FB-Line SAR, DPSTSA-200-10 SUPP-9

6.A FB-Line Minimum Shift Crew Composition

6.B Procedural Activities

8.A FB-Line Isotopics, from SAR

8.B FB-Line Process Area NCSS Maximum Permissible Inventories

8.C FB-Line Cold Feed Tank Capacities

8.D Cherricals Used in FB-Line Processing

8.E Summary Table of Results of Risk Matrix Binning for FB-Line Operations

8.F Summery Table of OSR/TS/SRS Documentation for FB-Line SAR and PHA Accidents

8.G Summary Table of Risk for FB-Line Bounding Accidents

8.H Safery-Related Systems and Components for FB-Line

8.I Safety-Related Systems Required for FB-Line Operations

\section{List of Figures}

Figure 1 Risk of FB-Line - Bounding Accidents Off-Site

Figure 2 Risk of FB-Line - Bounding Accidents Co-located 


\section{EXECUTTVE SUMMARY}

The safety analysis of the FB-Line Facility indicates that the operation of FB-Line to support the current mission does not present undue risk to the facility and co-located workers, general public, or the environment. This is based on the results of the hazard and accident analysis; the verification of the adeanuacy of the safety envelope by identification of controls, procedures and/or preventive and mitigative feanures against release of hazardous materials; and the implementation of aggressive safety management programs that ensure facility safery by adhering to principles of sound safety engineering and management pracrices.

The facility boundary is defined along with a description of hazardous materials and processes conducted within this boundary. A description of significant Safety-Related systems and design or procedural upgrades is provided Safety and authorization basis documents are identified.

The operations of FB-Line have been examined to ensure the completeness and adequacy of the operating envelope. A Preliminary Hazards Analysis (PHA) was performed as a complement to other existing safety basis documentation to identify significant radiological and chemical hazards associated with FB-Line, dominant accident scenarios, release pathways, and their causes and consequences. The Safety Evalustion Section of this Basis for Interim Operation (BIO), Section 8.0, contains summary information about the accidents and risks associated with operation of FB-Line, as defined in the PHA and in the FB-Line Safety Analysis Report (SAR). Section 8.0 discusses a review of DOE-STD1027-92 (Reference 1) which indicated that FB-Line is classified as Hazard Category 2 as a result of the plutonium (Pu) inventory. This section presents the impact of normal operations and postulared accident scenarios upon facility workers, co-located workers, and the public. The PHA identifies and examines existing safeguards for adequacy and recommends additional safeguards and/or analysis, if appropriate.

The frequencies and consequences associated with the accident scenarios which affect the operation of FB-Line were placed in "rist bins" which help illustrate the relative risk of the various scenarios. The results of this process were the identification of the following dominant accident scenarios, where dominant accidents are defined as Scenario Class I and II accidents (per the methodology documented in the PHA and in Section 8.2.2):

Class I Accidents:

Inadvertent Criticality

Ion Exchange Column Explosion

Class II Acoident:

\section{Single Level Propagated Fire}

These accidents are discussed in detail in Section 8.0 and the safeguards that prevent/mitigate exposure of the public, co-located workers, or facility workers are identified. To reduce the risk associated with the Class I event, Ion Exchange Column Explosion, administrative controls are employed, including Authorization Basis level requirements for radiation exposure limits on the resin, time limits for leaving a column in a loaded state, maximum nitric acid concentration allowed in contact with the resin, and resin temperature. Additionally, a more thorough analysis will be performed on the explosion and its effect on existing confinement. Westinghouse Savannah River Company (WSRC) 
commits to provide other measures as necessary to prevent a fatality from occurring and reduce this event to Scenario Class II or lower.

The other Class I event, Inadvertent Criticality, is classified as a Class I event for the facility worker based on its frequency as stated in the SAR and modified in this BIO. WSRC does not feel that any additional measures and/or limits are practical, nor necessary that reduce criticality frequency or consequence to Scenario Class II or lower.

FB-Line's programmatic approach to safety for facility workers, co-located workers, and the public is described (see Section 6.0) for the following areas: safety management goals and policies, emergency planning, fire protection, criticality safety, configuration control, installed process instrumentation, environmental compliance, industrial hygiene, occurrence reporting, review and audit, training, reconds retention, radiation protection, radioactive and hazardous materials control, quality assurance, waste management, maintenance, conduct of operations, and performance indicators.

Sections 7.0 and 8.0 of this BIO present the principal aspects of the operating envelope for the accident scenarios identified in the SAR and the PHA. The material presented provides both the preventive and mitigative features that are credited by WSRC for the yarious dominant accident scenarios. In defining the operating envelope of the facility, administrative controls (AC), commitments to complete an action, and certain design features (DF) not already defined as such in the authorization basis documents [e.g., SAR/Operational Safety Requirements (OSR)/Technical Standards (TS)], have been explicitly identified. The applicable ACs and DFs are included in Table 8.F, along with additional SAR/OSR/TS requirements. The use of bold face type indicates commiments contained in the text.

\subsection{INTRODUCTION}

FB-Line is located in the 200-F Separations Ares and is used to convert Pu nitrate, recovered from irradiated natural and depleted uranium in the 221-F Canyon, to Pu metal. The portion of Building 221-F which houses FB-Line was built either as part of the original construction (Levels 3 and 4) during 1951-53 or as part of the F-Area upgrade construction (Levels 5 and 6) during 1957-58. The facility has operated safely, with no major incidents over the lifetime of the facility (since 1954). Process operations were discontinued in January 1990 for routine maintenance sin projact upgrades. The work was completed in April 1990, as scheduled. During the shutdown, a program was undertaken to inspect exhaust ducts and clean them of any accumulation of Pu. Process operations remain discontinued pending Department of Energy (DOE) approval for restart. Note that anion process equipment is currently operated as required. With recent changes in the world power sturcture, the United States no longer requires a significant nuclear stockpile. The result for FB-Line is an eventual phase out of its operation over the next few years. When resturted, the mission of the facility will be to process existing inventories of $\mathrm{Pu}$ and Pu-bearing materials to achieve a suitable form for long term storage. Materials to be processed in FB-Line could include Pu solutions originating from F-Canyon inventories, aluminum-clad targets and fuels requiring stabilization, various at-risk solid inventories such as Pu-bearing process residues, oxides and/or metal compounds, or other materials identified by DOE.

The present analysis integrates the existing safety basis documentation, including a recently completed PHA, to demonstrate an adequate level of safety assurance associated with the planned operation of this facility during the interim until the commencement of decontamination and decommissioning. This is done by a discussion of the safety management program, an integrated safety evaluation, and presentation of the safety 


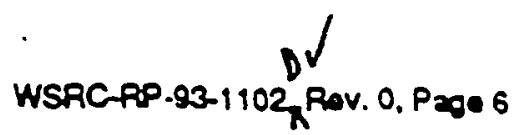

envelope. In addition, corrective or compensatory measures are discussed for idencified vuinerabilities.

\subsection{FACILITY DESCRIPTION}

FB-Line is located in Canyon Building 221-F, specifically in Sections 1 through 5 , on the third through sixth levels, plus the south loading dock on level 2, Section 1. The portion of the building that houses the process equipment is Class I - Blast Resistant Constuction. The processing equipment is enclosed in process enclosures (either cabinets or gloveboxes) to prevent contaminating operating areas. The processing equipment is confined to the fifth and sixth levels with the exception of the receiving tank for 221-F Canyon Pu product on the $31 / 2$ level. In addition to the processes described below, waste handling operations take place throughout the facility, and miscellaneous Pu vault storage operations take place in two vaults located in FB-Line on the third and fourth levels. The following subsections describe the functions of the process systems. Schematics are presented in the PHA.

\subsection{Cation Exchange}

The $\mathrm{Pu}$ in the 221-F Canyon Pu product solution is concentrated and decontaminated in one of four cation exchange columns of two segments each. The cation resin selectively sorbs the Pu from a relatively dilute solution. The cation resin eluant removes the Pu from the resin as a relatively concentrated solution of Pu required by the subsequent processing operations that convert the $\mathrm{Pu}$ to the metal. Cation exchange couples the F-Canyon process to the FB-Line metal conversion process. The main system components, in addition to the cation exchange columns, are two feed receipt tanks, four feed filters, two column head tanks, four product run tanks, and two product bold tanks.

\subsection{Precipitation and Filtration}

Precipitation produces Pu trifluoride cake from the Pu solution that was eluted from the cation exchange columns. The Pu concentrate from cation exchange and hydrofluoric acid are fed to the first stage precipitator to form large triflucride crystals. The slurry overflows to the second stage precipitator and is vacuum filtered to form a cake. The main system components are two concentrate feed tanks, two first stage precipitators, two second stage precipitators, two filter stations, two filtrate catch tanks, two filtrate neutralization tanks, a boat flush station, and a bos: Arrsin ru: tank

\subsection{Mechanical Line}

The filter boat containing Pu trifluoride is removed from the filtration station, monitored with a neutron probe for Pu content, and transferred to the Mechanical Line air drying station where dry, warm air is drawn through the cake to remove residual moisture. After air drying, the contents of the filter boats are dumped into roasting pans, which are then hydraulically nised into a roasting furnace. In the furnace, the material is converted to $\mathrm{Pu}$ tetraflucride and Pu dioxide mixture. The tetrafluoride/oxide mixture is mixed with metallic calcium in a reduction vessel and beated in an induction fumace to produce the metal. The main system components are four air drying stations, two conversion fumaces, two reduction fumaces, a pickling station, and a sampling station.

\subsection{Recovery}

$\mathrm{Pu}$ in solid scrap from onsite and offsite and miscellaneous solutions from FB-Line is recovered and transferred to 221-F Canyon for recycle through solvent extraction. Solids are dissolved in a slab tank, and the dissolver solution is filtered to remove refractory 


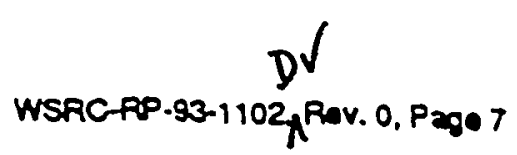

solids. Both dissolved Pu scrap and miscellaneous Pu-bearing solutions are prepared for sorption of Pu on anion exchange resin. The purified Pu solution eluted from the anion exchange resin is diluted and then transferred to F-Canyon. The main system components are two filtrate hold tanks, a recycle feed tank, a slag and crucible dissolver, a. filtrate run tank, two anion exchange columns, a waste tank, and a product run tank.

\subsection{Special Recovery}

Special processes were previously used to dissolve Pu oxides for blending with canyon processes. This operation has been shut down and left in a safe posture. Safe posture is defined as follows: Upon last operation of the dissolvers, a clean-out run was performed to reduce the Pu heel in the vessels. The process control computer has been de-energized. The cabinet floor was swept to remove any spilled Pu. The ventilation and fire systems are being maintained in the area, as well as the roving fire watch. Routine inspections include surveillance for nuclear safety concerns, liquid in the sump, and contamination leaks.

\subsection{RELEVANT OPERATIONAL HISTORY}

\subsection{Significant Events}

Ten events have occurred since approval of the SAR in 1988 which had the potential for facility bealth or safety consequences. Two involved exceeding a Nuclear Criticality Safety Supplement (NCSS) limit, five involved violation of posted Nuclear Safety Limits, and three involved deficiencies with Safety-Related ventilation interlocks. None had a serious impact on facility safety. None of these events were of an unanalyzed type or consequence. The occurrences are summarized in the subsections below.

In addition, some analytical deficiencies in the accident analyses from the current SAR resulted in underestimation of the accident consequences. These are 1) possible failure of the exhaust stack liner at seismic intensities below the design basis earthquake (DBE), 2) use of nominal inventories for process steps in accident analyses, rather than NCSS maximums, and 3) use of now outdated dose conversion values in accident analyses. The deficiencies are summarized in Section 8.0.

Another change to the accident analysis in the SAR is related to an expanded analysis of an existing event, criticality. A bydrogen deflagration event was analyzed as another possible initiator of an accidental criticality. This additional analysis is described in Section 8.0.

\subsubsection{Mechanical Line}

Separations Occurrence Report 90-09-31 describes an incident involving accumulation of condensate in the Mechanical Line glovebox exhaust header. Inspection of the east-west header of the Mechanical Line glovebox exhaust system identified the presence of less than 6 liters of liquid and solids bearing approximately a kilogram of Pu. Although more material was found than anticipated, no potential for criticality existed, as documented in the occurrence report. Procedural and equipment modifications bave been made to minimize future accumulation. These modifications include initiation of a program to inspect and monitor the Mechanical Line exhaust header system to prevent excessive accumulation of $\mathrm{Pu}$, as detailed in Reference 2, and installation of covers for pickling pans to reduce the amount of vapor which enters the exhaust duct. 


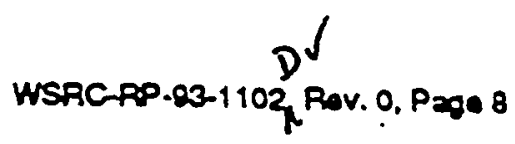

\subsubsection{Transuranic (TRU) Waste}

Occurrence Report SR--WSRC-FBLINE-1992-0047 describes an incident in which an error in Waste Tracking System software resulted in an NCSS limit violation. Calculation errors, attributed to inadequate procedures and computer software, resulted in NCSS limits being exceeded for 23 TRU waste drums sent to the Solid Waste Disposal Facility. Implementation of formal Technical Reviews including the Unreviewed Safety Question (USQ) process for all modifications, and establishment of a Configuration Control Board, will ensure that future procedural, hardware, and software changes are thoroughly reviewed for their impact on facility safety.

\subsubsection{Vault}

Five incidents (described in Separations Incidents SI-89-04-27 and SI-89-09-56, Separations Occurrence Report 90-12-55, and Occurrence Reports SR-WSRC-FBLINE1992-0024 and SR--WSRC-FBLINE-1994-0029) have occured in which Vault storage limits were exceeded, one of which involved violation of an NCSS limit. In the first occurrence (SI-89-04-27), material stored in two bin spaces of the vault exceeded the NCSS limits. Deficiencies were noted in the labeling and surveillance of vault inventory. Corrective actions to label the materials in the bins and floor spaces of the vault as well as a periodic surveillance of these materials in the vault were implemented. The three subsequent occurrences (SI-89-09-56, 90-12-55, and SR-WSRC-FBLINE-1992-0024) were discovered while implementing the corrective actions from occurrence SI-89-04-27. In these occurrences, material stored in the vaults violsted the nuclear safety posted (procedural) limits. The occurrences were discovered as a result of vault inventory surveillances and operator calculations based on the labeling of the material. The fifth occurrence (SR--WSRC-FBLINE-1994-0029) was discovered during a periodic surveillance of the vault inventory. Material was found in a starage container that exceeded the nuclear safety posted limit. This was an oversight that should bave been noticed during prior surveillances. The periodic surveillance did ultimately discover the discrepancy and enhancement of the vault inventory surveillance is being implemented. No potential for criticality existed as a result of any of the incidents, as documented in the respective reports. Improved administrative controls and surveillances have been implemented to minimize the potential for recurrence of these type incidents.

\subsubsection{Ventilation Interlocks}

Three incidents (described in Occurrence Reports SR--WSRC-FBLINE-1991-1034, SRWSRC-FBLINE-1991-1035, and SR--WSRC-FBLINE-1992-0013) bave occurred that involved deficiencies with ventilation system interlocks. In two of the incidents, initial wiring of the interlock was not per design. In the other, a temporary jumper was found to have been insdvertently left installed. Although none of the incidents resulted in any impact on facility safery, they collectively highlighted the need for improved Configuration Control and Work Control, which have since been implemented.

\subsection{Significant Equipment/Operations Changes/Upgrades}

Proposed changes to facility equipment for the ime period between SAR issuance and implementation of the USQ process in November 1991 were reviewed and documented through several programs, including the Safety Evaluation checklists, Test Authorization (TA) Program, and Work Order Program. Transition to a DOE defined Configuration Management Program for all of Savannah River Site (SRS) is underway. The USQ process was performed retroactively on all significant upgrades implemented from January 1990 until November 1991. No facility changes, including those implemented since 
November 1991 (including modifications described in Section 3.1.1 above), have been found to have any impact on the facility safery basis.

Facility upgrades for FB-Line were initiated in 1980 under Reference 3. The objectives of the restaration program were to:

1. Improve contamination control and reduce assimilation risk,

2. Meet applicable gridelines, regulations, and standards,

3. Inprove accountability of special nuclear materials,

4. Restore FB-Line to a condition suitable for use at projected production rates.

As a result of this program, seven projects have been completed, including construction of New Special Recovery (NSR) and the Plutonium Storage Facility (PSF), at a cost of S138 million, and five projects are in various stages of installation at an estimated cost of $\$ 98.1$ million. Of the 112 items identified in Reference 3, 79\% have been acted upon. The aforementioned completed projects account for 40 items, while projects in progress account for another ten. Non-project work is in progress on seven items, and work has been discontinued on five. Twenty-seven items have been completed without formal projects. The 23 remaining items will be analyzed for their impact and priority based on cost and benefic. None of the 112 items are Safety-Related, nor are they required for restart

Seven replacement cabinets have been installed in this program, four of which have been placed in operation. The four operational cabinets have reduced the radiation exposure of facility personnel due to remote process control computer operation and specially designed shielding and confinement. The remaining cabinets will not be placed in operation, since their primary purpose was to increase production capability and reduce radiation exposure by automating processes. Radiation exposure and production gosls can be met with existing cabinets.

Facility upgrade plans are constantly being reviewed and changed based on DOE needs, the current mission, and the availability of funds. Projects under consideration for implementation will improve facility safety, but are no: asired is keep the facility within the safety envelope defined by the SAR, OSR or TS. However, they will be evaluated under the USQ process.

\subsection{SAFETY DOCUMENTATION}

All authorization basis documents addressed in this section are listed in Table 4A for easy reference coly. The applicable authorization basis documents are subject to change, and for the most up-to-date listing, reference should be made to controlled document WSRC-IM93-61, "NMPD Authorization Basis Lists (U)", which contains all the authorization basis documents for the Nuclear Materials Processing Division (NMPD), and is updated as required. 
$\underset{\text { WSACAP.⿻8-1102 Rev. 0, Peos } 10}{D^{J}}$

Table 4.A

Applicable Authorization Basis Documents

\begin{tabular}{|c|c|c|c|}
\hline Document Number & Title & $\begin{array}{c}\text { Approvai } \\
\text { Date }\end{array}$ & $\begin{array}{l}\text { Approval } \\
\text { Authority }\end{array}$ \\
\hline DPSTSA-200-10 SUPP-9 & $\begin{array}{l}\text { Safety Analysis - } 200 \text { Area } \\
\text { Savannah River Plant FB- } \\
\text { Line Operations }\end{array}$ & $4 / 88$ & $\begin{array}{l}\text { DOE-SR \& } \\
\text { E. I. DuPont }\end{array}$ \\
\hline DPW-85-101, Revision 2 & $\begin{array}{l}\text { Operational Safety } \\
\text { Requirements for } 200-F \text { and } \\
200-H \text { Are2s (Excluding } \\
\text { Tritium and Waste } \\
\text { Management) }\end{array}$ & $8 / 94$ & $\begin{array}{l}\text { DOE-SR \& } \\
\text { WSRC }\end{array}$ \\
\hline WSRC-TN-45, Rev. 0 & $\begin{array}{l}\text { 221-F Building Technical } \\
\text { Standards (U) }\end{array}$ & Multiple & $\begin{array}{l}\text { DOE-SR \& } \\
\text { WSRC/ } \\
\text { E. I. DuPont }\end{array}$ \\
\hline DPSTS-NLM-85 & $\begin{array}{l}\text { Nuclear Incident Monitors } \\
\text { Technical Standard }\end{array}$ & $2 / 85$ & $\begin{array}{l}\text { DOE-SR \& } \\
\text { E. I. DuPont }\end{array}$ \\
\hline DPSTS-221-0.09 Sup. & $\begin{array}{l}\text { Nuclear Criticality Safety } \\
\text { Supplements Building 221-F, } \\
\text { JB-Line }\end{array}$ & Multiple & $\begin{array}{l}\text { DOE-SR \& } \\
\text { WSRC } \\
\text { E. I. DuPont }\end{array}$ \\
\hline $\begin{array}{l}\text { WSRC-TA-91-00002-12- } \\
\text { Extension (Rev. 2) }\end{array}$ & Storage of MK 42 Scrap & $1 / 94$ & $\begin{array}{l}\text { DOE-SR \& } \\
\text { WSRC }\end{array}$ \\
\hline
\end{tabular}

\subsection{Authorization Basis Documents}

\subsubsection{Safety Analysis Report}

The FB-Line SAR was writteñ üi he wid-1980's according to DOE Order 5481.1B, and analyzed the major hazards and dominant credible accident scenarios for normal processing operations. Consequence and frequency for these scenarios as they relate to the public are contained in the SAR; however, the consequences were based on nominal source terms and International Commission on Radiation Protection, Publication 2 (ICRP 2) dose factors.

The following table (Table 4.B) lists those sections of the existing FB-Line SAR that have been superseded by either new safety analyses or because the process is no longer used. The SAR sections that are indicated as being not applicable shall not be used in determining the approved safety envelope and Authorization Basis limits for operation of FB-Line. 
$D^{J}$
usRc-rip.9o-1100, Rev. 0, Poos 11

Table 4.B

List of Non-Applicable Sections from the PB-Line SAR, DPSTSA-200-10 SUPP.9

\begin{tabular}{|c|c|}
\hline $\begin{array}{l}\text { Non-Applleable or } \\
\text { Canceled Sections }\end{array}$ & Comaerts \\
\hline \multicolumn{2}{|l|}{ Chapter 1} \\
\hline Section 12.2 & The rist sammary in Section 1.22 hes been saperseded by the FB-Line BIO. \\
\hline \multicolumn{2}{|r|}{ 然 } \\
\hline $\begin{array}{l}\text { Sections } 2.1 .1 ; 2.1 .2 ; \\
2.1 .3 ; 2.1 .4 ; 2.1 .4 .1 ; \\
2.1 .42 ; \text { and } 2.1 .5\end{array}$ & 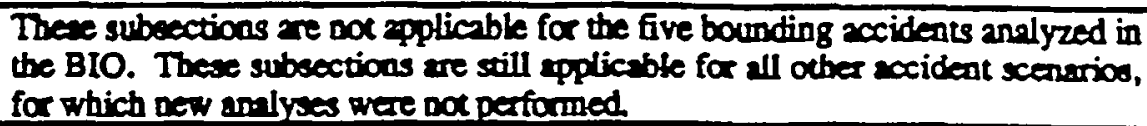 \\
\hline \multicolumn{2}{|l|}{ Chepter 3} \\
\hline $\begin{array}{l}\text { All Section and } \\
\text { subsections of Chaper } 3\end{array}$ & $\begin{array}{l}\text { The infarmation (including Tables and Figures) in Chspter } 3 \text { shall be retained } \\
\text { for historical purposes only and shall noc bo used as pert of the facility safery } \\
\text { earelope. }\end{array}$ \\
\hline \multicolumn{2}{|r|}{ 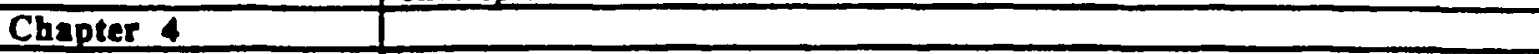 } \\
\hline Section 4.1 & Refer wo WSRC-1-02 for the WSRC appenizational structure. \\
\hline $\begin{array}{l}\text { Sections } 4.2 ; 4.3 ; 4.3 .1 ; \\
4.3 .1 .1 ; 4.3 .1 .2 ; \\
4.3 .1 .3 ; 4.3 .2 ; 4.3 .2 .1 ; \\
4.3 .2 .2 ; \text { and } 4.3 .3\end{array}$ & These sections have been superseded by Section 4.0 and Section 6.0 of the BIO. \\
\hline Sections 4.4 and 4.5 & $\begin{array}{l}\text { The information in these sections has been semperseded by Sections } 6.5 \text { and } 6.6 \\
\text { of the BlO. }\end{array}$ \\
\hline Sections 4.6 and 4.7 & $\begin{array}{l}\text { The tex and inspections are covered by the Safery-Relmed systems procedure and } \\
\text { the OSR and TS test and inspection requirements. Any unique hererds } \\
\text { associsted with freility operaion have been identified in the PHA a the BIO. }\end{array}$ \\
\hline $\begin{array}{l}\text { Sections } 4.8 ; 4.8 .1 ; \\
4.8 .2 ; 4.8 .3 ; 4.8 .4 ; 4.9 ; \\
4.9 .1 ; 4.9 .2 ; 4.9 .3 ; \\
4.9 .4 ; 4.9 .5 ; \text { and } 4.9 .6\end{array}$ & These sections have been sapperseded by Section 6.0 of the BIO. \\
\hline \multicolumn{2}{|l|}{ Chapter 5} \\
\hline $\begin{array}{l}\text { Sections 5.1.3; 5.3.3; } \\
5.4 .3 ; \text { and } 5.6 .3\end{array}$ & 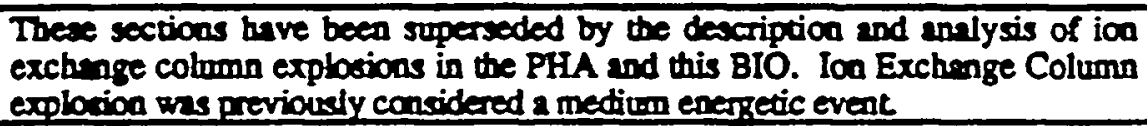 \\
\hline Section 5.1.4.2 & $\begin{array}{l}\text { Descriptions of fire midigating fearures are superseded by the Fire Hazards } \\
\text { Anslysis (FHA). }\end{array}$ \\
\hline Section 5.4.1.2 & $\begin{array}{l}\text { This section has been superseded by the earthquake consequence analysis in the } \\
\text { BLO. }\end{array}$ \\
\hline $\begin{array}{l}\text { Section } 5.5 \text { to include } \\
\text { all subsections. }\end{array}$ & $\begin{array}{l}\text { The radiological risks for FB-Line in this section have been superseded by the } \\
\text { ristas piven in the BIO. }\end{array}$ \\
\hline \multicolumn{2}{|l|}{ Chapter 6} \\
\hline Section 6.1 & This section hes been replaced by the Safery-Related Syseems List (Table 8.H.) \\
\hline Section 62.3 & This section is saperseded by Manulal WSRC-MM-93-13. \\
\hline Sections 6.3 and 6.4 & These sections are retsined for histarical purpoeses only. \\
\hline \multicolumn{2}{|l|}{ Chapter 7} \\
\hline Sections 7.1 and 7.2 & $\begin{array}{l}\text { The entire chspler } 7 \text { hes been repleced by the WSRC Quality Assurance (QA) } \\
\text { Proprem. }\end{array}$ \\
\hline \multicolumn{2}{|l|}{ Appendices } \\
\hline Appendix A & See source terms in this BDO for boumding accident scensios \\
\hline Appendix B & $\begin{array}{l}\text { The BIO uses the frequencien in these lables only. The reat of the tables in } \\
\text { Appendix B ure superseded by the BIO, bowever, the frequencies shall continue } \\
\text { w be used. }\end{array}$ \\
\hline Appendix C & This sopendix documents previous DOE comments end their resolution. \\
\hline Appendix D & $\begin{array}{l}\text { This appeadix is sepersoded by the FHA, excepp thar frequencies and frequency } \\
\text { calculations are recained. }\end{array}$ \\
\hline
\end{tabular}




\section{List of Tables in the FB-Line SAR Which are No Longer Applicable}

The following tables in the FB-Line SAR have been superseded or are no longer applicable and shall not be used in determining the FB-Line safety envelope.

Note: The frequency for criticality given in tables 5-23 through 5-26 shall be not be used. Also, the nominal release terms for third level, given in tables 5-29, 5-30, and 5-31, shall not be used.

$\begin{array}{ll}\text { Table Number } & \text { Page } \\ \text { Table 1-1 } & 1-5 \\ \text { Table } 1-2 & 1-7 \\ \text { Table } 1-3 & 1-8 \\ \text { Table } 2-2 & 2-6 \\ \text { Table } 2-3 & 2-7 \\ \text { Table } 4-1 & 4-19 \\ \text { Table } 4-2 & 4-24 \\ \text { Table } 4-3 & 4-26 \\ \text { Table } 4-4 & 4-28 \\ \text { Table } 4-5 & 4-29 \\ \text { Table } 4-6 & 4-32 \\ \text { Table } 4-7 & 4-34 \\ \text { Table } 5-2 & 5-13 \\ \text { Table } 5-7 & 5-31 \\ \text { Table } 5-34 & 5-79 \\ \text { Table } 5-35 & 5-80 \\ \text { Table } 5-36 & 5-82 \\ \text { Table } 5-37 & 5-86 \\ \text { Table } 5-38 & 5-88 \\ \text { Table } 5-39 & 5-89 \\ \text { Table } 5-40 & 5-90 \\ \text { Table 6-1 } & 6-2 \\ \text { Table 6-2 } & 6-3 \\ & \end{array}$

The following figures in the FB-Line SAR have been superseded and shall not be used in determining the FB-Line safety envelope.

Figure Number

Page

Figure 41

Figure 4-2

Figure 43

Figure 4-4

Figure 4-5

Figure 46

4-2

43

48

4-22

4-25

431

The information in the table was developed by reviewing the SAR to determine those sections that reflected current and planned facility operations. Any section which contained incorrect information was reviewed to determine if any information in the section was still applicable to the facility safety envelope. If the section which contained incorrect information did not directly impact the facility safety envelope or had been superseded by 
other documents, the section was indicated as being non-applicable for use in determining the safery envelope. In some cases the deleted section contained specific requirements that could affect the facility safety envelope. If a specific requirement that affected the facility safety envelope was identified in a section that was deleted, the requirement was retained and is included in the appropriate section of Table 8.F. In some cases a section may contain incorrect material but still contain a significant amount of correct material. In this case, it was determined to retain the material for historical reference only. The comment section in Table 4.B indicates those sections of the SAR that have been deleted because they were superseded by other documents or because the equipment or process is no longer used, and those SAR sections that should be retained for historical purposes.

\subsubsection{Operational Safety Requirements and Technical Standards}

The purpose of an OSR document is to define the envelope of authorized operations of nonreactor nuclear facilities at SRS, and formally document the requirements for operation in the following categories: Safety Limits and Limiting Control Sertings, Limiting Conditions for Operations, Surveillance Requirements, Design Features, and Administrative Controls. The current approved OSR was written in 1985 to DOE Order 5481.1B, and was last revised in August, 1994.

TS are a collection of contractor and DOE approved documents which define the actual process limits within which the facilities are operated. They specify the requirements and bases for basic variables within which the process must be operated for reasons of safety, quality, and/or limitations of known technology. These requirements are within the boundaries of safe conditions reported in the OSR. Revision to the current approved TS for FB-Line is an ongoing process. TS pertaining to FB-Line were most recently revised in December 1980.

TS originated at the SRS in the early 1960 's, as a requirement of the Atomic Energy Division (AED) of E. I. DuPont de Nemours \& Company, the original contractor at the Site. TS were the primary control point in the AED procedural system for process safety and efficiency. They were based on Technical Manuals that included experimental results and detailed descriptions of processes. Operating manuals and procedures were written to ensure TS limits were maintained with a significant margin of safety.

\subsubsection{Nuclear Criticality Safety Supplements}

NCSS are a collection of contractor and DOE approved documents which specify conditions and limits within which operations must be conducted for reasons of nuclear criticality safety. The most recent revision to an FB-Line NCSS was in March 1992.

\subsubsection{Test Authorizations}

A TA is a contractor and DOE approved document which authorizes temporary deviations from TS. The purpose of a TA is to conduct process suidy trials with plant equipment or to authorize non-standard operations. Limits defined by the TA are within the boundaries of safe operations specified in the OSR and SAR and therefore are always within the facility Authorization Basis. Like the TS, TAs originated at the SRS in the early 1960 's to provide for operational flexibility within safe limits. There is currently only one applicable TA for FB-Line operations. 
DV
WSRC-RP.93-1 100 NRev. 0, Peop 14

\subsection{Other Documents}

\subsubsection{Fire Hazards Analysis}

The purpose of the FHA (Reference 4) is to evaluate the fire protection and life safery features of FB-Line, and to determine whether or not the objectives of DOE Order 5480.7A have been satisfied. WSRC commits to have a WSRC-approved FHA prior to declaration of readiness for restart (C).

\subsubsection{Linking Database}

The Liniaing Database provides a road map of the relarionstips between authorization basis document requirements and field implementation of those requirements. The database itemizes the surveillance requirements and limits included in the authorization basis documents (i.e. SAR, OSR, and TS). Duplicate requirements from these authorization basis documents are combined into a single entry with reference to all applicable source documents. The datsbase links the requirements and limits from these documents to various program and procedure references which are used for tracking or implementation of the requirement. The Linking Database program and procedure references identify implementation methods such as the Surveillance Test Program, the Installed Process Instrumentation (IPn) Program, the Preventive Maintenance Program and the facility's operating, maintenance, test, and Safety-Related systems procedures. Prior to declaration of readiness for restart, the Linking Database will contain information that captures any existing or new implementable safety requirements trom the BIO (C).

As indicated in the execuive summary, new requirements contained throughout this BIO have been explicitly identified. Commitments are noted in bold and identified by a $C$ in parentheses. Bold type is used to allow easy identification of commitments. This convention is not used in Table 8.F since these requirements are easily identified. Prior to declaration of readiness for restart, commitments identiffed in the BIO will be incorporated into an appropriate issues/commitment tracking system (C).

\subsection{COMPLIANCE STATUS}

Temporary Exemption Requests to exempt FB-Line from compliance with DOE Orders 5480.22 and 5480.23 have been approved. These Exemption Requests are documented in WSRC-RP-93-668-005 as SRS-DOE-5480.22-EX-93-009 and in WSRC-RP-93-668-007 as SRS-DOE-5480.23-EX-93-004. A temporary versus permanent exemption was granted due to the uncertainty of the future mission of FB-Line, dependent on the outcome of the Environmental Impact Statement ( EIS) for Interim Management of Nuclear Materials at the SRS. A final decision for Permanent Exemption Requests will be made within 60 days of the EIS Recond of Decision by DOE. This BIO will be in effect for the operational life of the FB-Line facility and reviewed and updated annually, unless the Permanent Exemption Requests cannot be supported. In this latter case, subsequent safety documentation upgrades per DOE Orders 5480.22 and/or 5480.23 would supersede the BIO when approved.

Documentation of the assessment of compliance with all other Level 1 DOE Orders (51 onders important to worker safety and protection of the public and the environment) will be completed prior to startup. Identified non-compliances with requirements will have en improvement plan in place and/or generate a Compliance Schedule Approval (CSA)/Exemption Request with identified compensatory measures. Over ninety DOE 


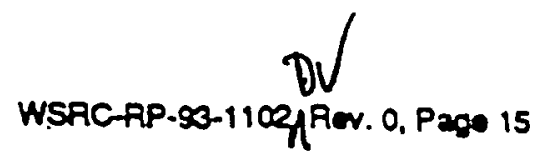

Order Compliance Packages have been issued in final form and are contained in WSRC. RP-90-12, "DOE Directives Assessment and Compliance Plan".

Following the compliance verification step, a field validation of selected DOE Orders will be completed. Prior to completion of the WSRC Operational Readiness Review (ORR) for this restar, all documented and active compensatory plans, CSAs, and Exemption Requests, established by the DOE Order Compliance Program, will be revalidated.

\subsection{SAFETY MANAGEMENT}

The principal safety concerns for FB-Line are:

a. Ionizing radiation from fixed radiation sources and from radiasctive contamination

b. Loss of process fluids and aerosols from vessels or systems, so that hazardous materials can be released to the facility atmosphere and environment

c. A criticality eveat

d. Normal industrial hazards

e. Chemical hazards.

The following goals and requirements exist to address the principal safety concems. The remaining paragraphs of Section 6.0 describe the management programs which exist to ensure these goals/requirements are met. It should be noted that all program descriptions herein assume compliance with " $A$ " findings from the WSRC ORR prior to startup, as required by Procedure Manual 12Q "Operationsl Readiness Review Manual".

a. Maintain individual occupational ractiation exposure as low as reasonably achievable (ALARA),

a. Maintain non-radiological atmospheric and liquid releases within regulatory limitis;

c. Maintain offsite radiological dose (to the public) ALARA by limiting radioactive releases to the lowest possible level Maintain offsite doses within regulatory limits,

d. Maintain operations activities within the facility Authorization Basis,

e. Operate in accordance with applicable industrial safety requirements.

It is the stated policy that the safety and protection of employees and the public is the first priority of WSRC and that work will stop immediately rather than conduct a job in an unsafe manner. Further, the safety philosophy is that all injuries can be prevented and that any hazards which may result in injuries must be safeguarded. To accomplish these ends, a comprehensive safety program protecting facility workers from industrial and process hazards has been implemented through Procedure Manual 8Q, "Westinghouse Savannah River Company Employee Safety Manual (U)", and Manual WSRC-IM-90-135, "Savannah River Site Process Safety Management Manual (U)". These programs, in concert with the SAR analyses, PHA, criticality studies, procedure development process, 
training, etc. all serve to ensure that the hazards to facility workers are understood and controlled.

In particular, the SRS Process Safety Management (PSM) Program concerns itself with protecting facility workers from process-based hazards. The principal objective of the PSM Program is to provide a periodic, systematic review of each SRS process having the potential to result in a catastrophic accident in order to minimize injuries and property damage resulting from process-related hazards. The program is constructed around the Process Hazards Review (PHR) which is an organized effort to identify and evaluate the hazards associated with various SRS processes and to identify potential improvements in process safety.

The remainder of this section specifies the administrative framework for safe facility operation. It also provides an overview of the administrative control documents used to maintain safe operations and achieve the goals stated above. The administrative control documents for the facility are prescribed to ensure that basic and important decisions are made only after appropriate review and that decisions that could significantly affect safety receive independent review.

\subsection{Management Policies}

General management policies and guidance are contained in WSRC-1-01, "Westinghouse Savannah River Company Policy Manual", and include the following specific policies:

a. Administrative and procedural controls delineate clear lines of responsibility and methods for safe operation under normal and emengency conditions,

b. All changes to components, equipment, procedures, and systems required for facility safety require independent review,

c. Decisions that have significant safety implications receive independent review before final approval by management,

d. Safe boundaries fos operation are carefully defined and approved by management, and communicated to affected parties.

Management policies are implemented through procedures approved by WSRC management.

\subsection{Organizational Structure and Management Responsibilities}

The majoc functions of the SRS are assigned to divisions, each under the direction of a Vice President (VP). The VPs report directly to the WSRC President. The NMPD VP is responsible for operations of nonreactor facilities within NMPD, including FB-Line. The Separations F-Area Manager reports to the VP and is responsible for the activities conducted in F-Area. Each facility in F-Area is managed by a Facility Manager. NMPD Engineering provides support to F-Area facilities through Separations Engineering. Regulatory Programs, and Engineering Programs and Assessments. This organizational arrangement is presented in WSRC-1-02, "Westinghouse Savannah River Company Organization Chars".

The FB-Line Facility Manager reports to the Separations F-Area Manager and is responsible for managing all aspects of FB-Line facility operations including Radiological Control, Industrial Safety, QA, personnel staffing, training, procurement, and facility 
maintenance. The FB-Line Facility Manager carries out these responsibilities by direction of, and delegation to, the various managers and support personnel reporting to him/her. Specifically, the Facility Manager is responsible for the following, as specified in Procedure Manual S1-1-1 "FB-Line Administrative Procedures and Policy Manual (U)", Item 5.01, "FBL Shift Operating Crew Staffing Requirements (U)":

a. Overall facility operation (He or she delegates in writing the succession to this responsibility during absence.)

b. Operation of the facility in accordance with approved OSR and TS

c. Facilitation and control of procedure changes and physical modifications in plant configuration and coordination of the activities of all work groups within the facility

d. Ensuring that each on-duty shift is composed of at least the minimum shift crew composition shown in Table 6.A (Any temporary deviation from these requirements must be justified by facility-specific analysis.)

e. Ensuring that on-call support personnel are assigned and that technical support personnel are availabte to provide technical assistance to the production staff

f. Ensuring that all facility operations are performed under the direct supervision of a trained First Line Supervisor (FLS)

g. Ensuring that facility control is carried out by qualified operators according to written procedures

b. Ensuring that FB-Line FLS and Control Room Operatars are subject to limitations when being assigned work outside of their regular schedules (These limitations are included in Procedure Manual 5B, "WSRC Human Resources Policies, Practices, and Procedures (U)", Practice 2.23, "Exempt Employee Overtime Administration (U)", and Procedure Manual 2S, "Conduct of Operations (U)", Procedure 5.1, "Facility Oneration Organization and Administration (U)".)

i. Ensuring that qualified operators are in the Coupling Operating Room and the Central Control Room at all times

j. Ensuring the Shift Operations Manager or FLS mans the Operations Command Center at all times.

The FB-Line organization interfaces with various other WSRC organizations in accomplishing the FB-Line mission. Some of these organizations include: the Radiological Control Operations Section which provides oversight of the Radintion Protection Program to assure that the radiation exposure of the facility personnel is maintained ALARA; the Facility Safety Evaluation Section which conducts independent review of safety documentation and evaluates compliance to selective DOE orders; the Site Safety Review Committee which meets periodically to assess the adequacy of environment, safety, bealth, safeguands, security, and QA; and the Facility Operations Safety Committee, which meets periodically to review occurrences and to ensure significant issues are adequately evaluated. 


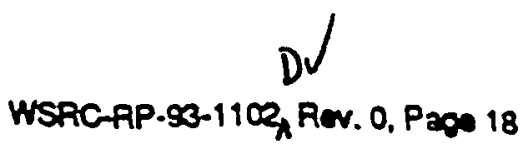

The Shift Operations Manager (SOM) is responsible for the local command function of the facility. During any absence of the SOM from the facility, a designated, qualified individual assumes the command function.

Table 6.A - FB-Line Minimum Shift Crew Composition

$\begin{array}{lccccccc}\text { EACTINYMODE * } & \text { SOM } & \text { ELS } & \text { OP } & \text { NSS } & \text { RCO } & \text { Maint } & \text { STE } \\ \text { Operation } & 1 & 2 & 9 & 1 & 3 & 2 & 1 \\ \text { Standby } & 1 & 1 & 7 & 1 & 2 & 2 & 0\end{array}$

SOM - Shift Operations Manager
FLS - First Line Supervisor
OP : Operatar
NSS - Nuclear Safety Specialist
RCD - Radiological Control Operations
Maint - Maintenance Personnel
STE - Shift Technical Engineer

- The facility is considered to be in Operation mode when one or more process arcas are processing Pu material. When no process areas are processing Pu material, the facility is considered to be in Standby mode. Process areas are: Cation Exchange, Mechanical Line, Recovery, and Precipitation/Filtration.

\subsection{System Of Control Documents}

A formalized system of procedures is employed, as described in Procedure Manual 11Q, "WSRC Administrative and Procedural Controls System for SRS Resctor and Non-reactor Nuclear Facilities $(U)^{n}$, to ensure that the facility is operated and maintained as prescribed by the OSR and TS. The SAR, OSR and TS provide the requirements and bases for safe facility operation. These documents, in turn, are implemented by lower tier procedures and documents. The lower ier procedures and documents contain limits on variables and system operation that are at least as restrictive as those in the OSR and TS.

The SAR, OSR and TS are the primary safety control documents. Additional documents and controls are described below. A Safety nomumentation Database, also referred to as a "Linking Database" (see Section 4.2.2), has been created to assist in locating and relating safery documentation for FB-Line. This database itemizes surveillance requirements and limits contained in the SAR, OSR, TS, NCSS, and TA. The database shows the relationship between the requirements and limits from these documents and shows how they apply to different process areas and systems. The database also identifies the FB-Line procedures which implement the requirements contained in the higher tier documents such as OSR and TS. Access to this database will be controlled by a procedure which is currently being developed by the FB-Line Procedures Group.

6.3.1 Contractual Agreement - The contract describes the relationship between the contractor (WSRC) and the contracting officer (DOE).

6.3.2 Unreviewed Safety Question Process-The WSRC USQ process is required by DOE Order 5480.21 and is implemented by Procedure Manual IIQ, Procedure 3.10, "Nonreactor Nuclear Facility Unreviewed Safety Questions" (latest revision), and lower tier NMPD or Separations procedures. All proposed activities such as facility modifications, equipment modifications, operating procedure revisions which change the operational steps or intent of the procedure, other activities that could affect safe operation of the facility, and potential inadequacies (analytical errors or omissions) in the facility 
safery analysis are evaluated by the USQ process. The USQ process evaluation determines if the proposed activity or porential inadequacy is within the current DOE approved facility safety envelope and the risk (frequency or consequences) associated with the proposed activity are within the DOE accepted facility risk. The proposed activity must be approved by DOE if the USQ evaluation indicates that a USQ is involved with the activity. If no USQ is involved, WSRC implements the activity without DOE approval. Guidelines for determining if a USQ exists, based on changes in frequency and consequence of accidents, are contained in Procedure Manual 11Q, Procedure 3.10 (latest controlled and issued revision).

6.3.3 Authorization of Startup by DOE - DOE approval is required prior to facility startup if the facility operation/process will be restarted after.
a. An OSR violation from exceeding a Safery Limit
b. A DOE-mandated shutdown
c. Discovery of a condition that results in a USQ
d. Being non-operational for mare than 12 months
e. Substantial facility modifications.

6.3.4 Procedures - Procedures are established, implemented, and maintained to address the activities specified in Table 6.B. They are reviewed to ensure conformance with the following:

a. Procedures are approved by appropriate management levels in scoordance with approved procedures, which have been authorized by the Facility Manager or designce.

b. New procedures and procedure changes that may have a potential impact on facility configuration, operation, nuclear safety, industrial safety, or environmental and bealth regulation compliance, are reviewed by Engineering:against applicable requirements. Other disciplines may be required te ifich and approve a procedure based on the subject matter.

All procedures have a USQ screening/evaluation performed and do not authorize operation outside the Authorization Basis. Special Procedures provide instructions and limits for non-routine operations and are good for one use only. 


\section{Table 6.B - Procedural Activities}

A. Administrative Procedures to govern:

1. Authority and responsibility for facility safe operation and shutdown

2. Equipment control (e.g., locking and tagging)

3. Procedure adherence

4. Procedure review and approval

5. Conduct of operations

6. Control of maintenance work

7. Control of modifications

B. Operating Procedures to govern:

1. Startup, operation, and shutdown of facility systems and equipment

2. Surveillance Requirements

C. Maintenance Procedures to govern:

1. Control of routine maintenance, inspection, calibration, and test activities

2. Preventive and Corrective Maintenance Program(s)

D. Alarm Response Procedures to govern initial validation and corrective actions in response to control room alarms for safety systems

E. Procedures to define the methods for conrecting abnormal facility conditions

F. Implementation of IPI Program

G. Implementation of the facility Fire Protection Program

H. Implementation of the facility Emergency Response Program, Emergency Preparedness Administrative Procedures (EPAPs), and Emergency Plan Implementing Procedures (EPIPS)

1. Livplementation of the Radiation Procection Program to limit materials released to the environment and to limit personnel exposure

J. Implementarion of the facility QA Program

K. Inplementation of the facility Nuclear Criticality Safety Program

L. Implementation of the facility Industrial Hygiene (IH) Program 
WSAC-RP.so-110epher. 0, Pege 21

6.3.5 Emergency Plan - The Site Emergency Plan, Procedure Manual 6Q, "Westinghouse Savannah River Company Savannah River Site Emergency Plan", defines appropriate response measures for the management of emergencies involving the SRS. The plan forms the policy basis for the conduct of operations related to emergency planning, response, and consequence mitigation. Line organizations are responsible for.

a. Implementing facility emergency preparedness programs consistent with Procedure Manual 6Q

b. Maintaining area/facility emergency plan annexes and associated implementing procectures and updating on an annual $\alpha$ as needed basis

c. Ensuring an adequate facility Emergency Response Organization (ERO) is established and maintained

d. Providing technical support for drill/exercise scenario development

e. Implementing facility ERO training drills

f. Determining corrective actions; coordinating and tracking resolution of open area/facility emergency preparodness items

g. Implementing facility protective action drill program

6.3.6 Facility Fire Protection Program - The facility Fire Protection Program is described in Procedure Manual S1-1-1, Item 3.02, "FB-Line Facilities Fire Protection Program Plan (U)". This plan gives an overview of the responsibilities of personnel involved with fire protection and references facility procedires to minimize the following:

a. Threats to the public or worker bealth or welfare resulting from a fire

b. Hazands to site personnel from a fire

c. Delays to important DOE programs as a result of a fire

d. Safety and control system or property damage related to a fire.

The Fire Protection Program gives an overview of the responsibilities of personnel involved with fire protection and references facility procedures that accomplish the following objectives:

a. Fire Prevention

i. Maintaining the fire-resistant construction of the structure in a manner that does not decrease the fire resistance of the structure

ii. Control of combustibles

iii. Control of ignition sources

iv. Facility inspections

v. Handling of combustiblefflammable liquids and gases

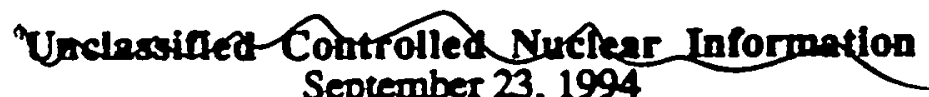




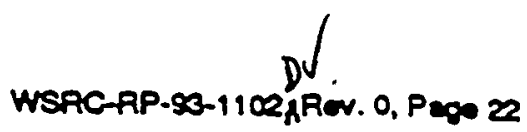

b. Fire Control

i. Automatic detection/suppression and alarm systems

ii. Fire Watch (If a fire detector or alarm is found inoperable, a Fire Patrol inspects the affected fire detection zone within four hours of discovery, maintains this watch on a four hour shift until the system is returned to operability, and provides backup suppression as necessary.)

iii. Adequate fire barriers (e.g., walls, doors, dampers)

iv. Proper availability and maintenance of facility fire fighting equipoment

v. Identification of facility fire fighting personnel, responsibilities, and training

vi. 24-hour fire fighting coverage

vii. Proper Fire Control Pre-Plans that adequately cover manual fire fighting methods and possible emergency conditions during fire fighting and that identify. special hazands within the facility.

FB-Line is not currently in full compliance with all DOE Order 5480.7A fire protection requirements. The FHA, M-FHA-F-00022, Rev. 4, lists all known FB-Line deficiencies with respect to fire protection. One significant issue was identified in the FHA and that is the possibility of a fire on the third or fourth level of FB-Line causing an unfiltered release of radioactivity to the environment. This issue has been addressed and is discussed in Section 8.3.2.3 of this BIO.

6.3.7 Nuclear Criticality Safety Program - The Nuclear Criticality Safety Program, as defined in Manual WSRC-IM-93-13, "Nuclear Criticality Safety Manual", is implemented by Procedure Manual 1E7, "NMPD Engineering Procedures Manual (U)", Procedure T-410, "NMPD Nuclear Criticality Safety (U)", and Procedure Manual S1-1, "Separations Program Administrative Manua", Procedure OP4.14-02, "200-Area Criticality Audit Committee Charter (U)". This program is a formal, documented system for the control of nuclear safety parameters and their bases, identification, and verificarion, which provides a tracking system for the stans of audit findings. The Facility Manager ensures:

a. Nuclear Criticality Safery Evaluations (NCSEs) are performed when required

b. Facility persoanel receive nuclear criticality safety training

c. Operations are controlled to comply with established subcritical margins

d. Nuclear Incident Monitors (NTMs) are installed and maintained as required for criticality derection

c. Compliance with DOE Orders and American Nuclear Society (ANS) Standards.

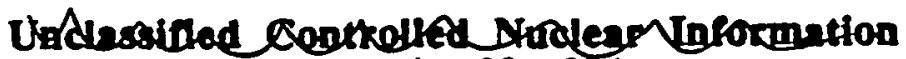
September 23, 1994 
This program has been successful in maintaining nuclear criticality safety in FB-Line. There have been no criticalities.

The current approved SAR for FB-Line does not explicitly address or document requirement statement 7.c.(8) from DOE Order 5480.24. The information in the following paragraph is included in this BIO to satisfy the requirement that the SAR include a description of the technical practices and measurement control program used in determining the quantities of fissionable material present in any location and the uncertainties of the measured values.

In response to the requirements of statement 5480.24 7.c.(8): The current approved FBLine SAR has a section on process and facility description (Section 3.2) and engineered safety feanures (Section 3.3), but all the information indicated by this requirement is not present in the SAR. The information does exist in FB-Line documents relating to material control and accountability plans. These documents include (1) NMP-SBT-91-225, "FBLine Measurement and Control Program Plan", Rev. 0, June 1992, (2) SSE-MCP-920036, "Static LEID", June 1992 (this document is classified), and (3) NMP-SBQ-930004, "FBLine Material Control and Accountability Implementation Plan", July 1993.

In addition, a Double Contingency Analysis (EPD-NCE-94-0144) for FBLine. process operations will be completed and issued before declaration of readiness for restart (C).

6.3.8 Nuclear Criticality Safety Evaluations - NCSEs are the base document for nuclear criticality safety control. Processes must be shown to be subcritical under all normal and credible abnormal operating conditions. NCSEs are used to evaluate new processes or process changes before any fissile material is processed, stored, or shipped and document the calculations and judgments used in determining that nuclear criticality safety is ensured.

6.3.9 Conffguration Control - A graded Configuration Control Program as described in Procedure Manual 7E, "Configuration Management Manual (U)", is implemented according to Reference 5 that:

a. Identifies, do wisitits, functionally tests the Safety-Related systems

b. Ensures that changes are properly developed, assessed, appioved, issued, and implemented through the use of the following:

i. Change Control Review Boards

ii. Setpoint control

iii. Design control

iv. Software control

v. Technical review and approval process, including performance of a USQ screening/evaluation and review of environmental documentation

vi. Document control 


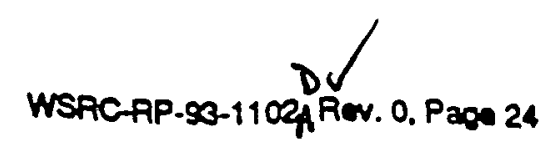

vii. Verification and acceptance process

viii. Compliance auditing

c. Maintains a system for recording, safeguarding, and indicating the status of technical baseline documentation.

6.3.10 Installed Process Instrumentation - IPI is identified and programmatically controlled, according to Procedure Manual 1Q, "Westinghouse Savannah River Company Quality Assurance Manual (U)", Procedure QAP 12-2, "Control of Installed Process Instrumentation (U)", when utilized to monitor process variables (such as level or temperature) used to comply with the requirements of the OSR and TS. Controls include the following:
a. Traceability of OSR/TS-related IPI items
b. Calibration frequencies for OSRTS-related IPI irems
c. Evaluation of OSRTS-related IPI items found outside of calibration
tolerances.

6.3.11 Environmental Compliance Program - Facility and co-located workers and the public are provided protection from normal operational releases and exposures as well as postulated accidental releases of bazardous materials through facility compliance with its Environmental Complience Program, as described in Procedure Manual 3Q, "Environmental Compliance Manual (U)". This manual is designed to comply with applicable federal and state environmental regulations, and consists of:
a. Administrative procedures
b. Training
c. Physical controls.

FB-Line is operated in compliance with the applicable state and federal permits and regulations. Liquid waste is directed to the Effluent Treatment Facility (ETF) or the F-Area Tank Farm by way of F-Canyon. Both ETF and the Tank Farm are permitted by the state as waste water treament facilities. Solid waste is characterized when generated and disposed of in the proper permitted Waste Management facilities. Radioactive releases are monitored in compliance with requirements of the National Emission Standard for Hazardous Air Pollutants (NESHAP). All radiosctive releases are significantly less than the DOE and Environmental Protection Administration (EPA) standard for dose to the public at the site boundary.

6.3.12 Industrial Hygiene Program - An IH Program, as described in Procedure Manual 4Q, "Industrial Hygiene Manual (U)", is implemented to achieve compliance with DOE orders and DOE-prescribed IH standards for controlling occupational exposures to specific chemical, physical and biological hazards. The IH program establishes essential elements to address identification, evaluation, and control of these hazards within the workplace. 
WSRC-AP.93-1100 DVRev. 0, Pogo Zs

\subsection{Events, Conditions, and Concern Investigations, and Occurrence Reporting}

Events, conditions, and concerns that may involve safety, health, safeguards \& security, or environmental implications are controlled by WSRC policy, as described in Procedure Manuals 9B, "Site Item Reportability and Issue Management (SRRM) (U)", 9B3, "NMPD - Separations Requirements for SIRIM (U)" and 2S. It is the policy of WSRC to encourage a positive attitude toward reporting occurrences and that occurrences be consistently reported to ensure that both DOE and WSRC line management, including the Office of the Secretary, are kept fully and currently informed of all events that could: (1) affect the health and safety of the public; (2) impact the operation of DOE facilities; (3) degrade the environment; or (4) endanger the health and safety of workers. It is also the policy of WSRC that there be a.system for determining appropriate corrective actions and for ensuring that such action is effectively taken. Specifically, it is WSRC policy to ensure the following:

a. Timoly identification, categorization, notification, and reporting $\infty 0$ DOE and contractor management of all reportabte occurrences at DOE-owned or -operated facilities

b. Timely evaluation and implementation of appropriate corrective actions

c. Submission of all required reports to the Occurrence Reporting and Processing System (ORPS) database to provide lessons leamed to other DOE operations and facilities to prevent similar occurrences

d. Review of reportable occurrences to assess significance, roor causes, generic implications, the need for carrective actions, and lessons learned.

\subsection{Revier And Audit}

Comprehensive safety reviews and audits are performed to assure compliance with applicable safety codes, standards, and good safety practices. The reviews and audits fall into one of the following categories:
a. Independent audits, reviews, and safety appraisals
b. Criticality andits
c. ORRs.

The internal review system is evaluated, on the average, every 42 months, per Procedure Manual 1B, "Westinghouse Savannah River Company Management Requirements and Procedures (U)", Procedure MRP 5.09, "Triennial Reviews of Independent Review and Appraisal Systems (U)".

\subsection{Training}

Personnel receive initial training in the safety aspects of jobs with periodic retraining in cerain areas (e.g., chemical hazards and self-monitoring of radiation exposure). Personnel also receive training in emergency actions as described in area and site emergency plans and procedures. Personnel involved in operations affecting nuclear sefety are trained in their tasks prior to assuming the responsibilities of the position. Training requirements are decailed in accordance with administrative procedures. 
Initial training, continuing training, and retraining of qualified supervisors and qualified operators are carried out by formal classroom instruction and on-the-job experience. Initial operator qualification is based on a demonstrated acceptable level of competence and performance. Initial operator qualification depends on satisfactory completion of comprehensive examinations and operating evaluations; satisfactory physical condition; general health; and higher supervision's judgment of general qualifications.

The training program (Procedure Manual S1, "NMPD and WMER Organization and Administration Manual $(U) "$, Procedure OP5.10, "Personnel Selection, Training, Qualification/Certification Program (U)" ${ }^{n}$ ) addresses the positions identified for accreditation. Performance-based training is used for designing and implementing all training. Continuing training and reexamination on emergency response procedures are conducted annually, and biennially for other procedures important to safe operation. Requalification is conducted biennially. The bases for both initial qualification and requalification are documented. Documentation includes 2 copy of the most recent test results and grades.

DOE has approved an exemption from DOE Order 5480.18A for the FB-Line facility. The facility does not intend to have its training program accredited.

\subsection{Facility Operating Records}

Records retention practices are in accordance with the SRS QA Plan and Records Management directive(s). Specifically, the following documents are retained as records for the period specified by the FB-Line Rocords Retention Schedule and Procedure Manual S11-1, Item 2.17, "FB-Line Document Control and Records Management (U)":

a. Records and logs of facility operation

b. Records and logs of principal mainterance activities, inspections, repairs, and replacements of principal equipment items related to nuclear safety

c. All reportable eventa/occurrences

d. Records of surveillance activities, inspections, and calibrations required by OSR and TS

e. Records of changes made to procedures

f. Records and drawing changes reflecting facility design modifications made to systems and equipment described in the SAR

g. Records of radiation exposure for all individuals entering radiologically controiled areas

h. Records of gaseous and liquid radioactive material released to the environment

i. Records of facility tests and experiments

j. Records of training and qualification for current members of the facility Operations staff

Unchastifed Controtied Nuelear Diformation Seprember 23, 1994 


\subsection{Quality Assurance.}

The facility QA Program, through the site QA Program (Procedure Manual 10), :

a. Is implemented through written procedures and instructions

b. Applies to construction, operation, maintenance, research, development, and design

c. Requires that sufficient reconds be maintained to preserve the technical beseline documentation

d. Supparts independent audit/verification requirements to determine compliance with the site QA Program

e. Provides for a graded approach to the application of QA requirements.

\subsection{Waste Management}

The DOE policy as outlined in DOE Order 5820.2A "Radioactive Waste Management", is that any radioactive, hazardous or mixed waste, shall be managed in a manner that assures protection of the health and safety of the public, DOE and contractor employees, and the environment. The generation, treatment, storage, transportation, and/or disposal of radioactive, hazardous, or mixed waste shall be accomplished in such a manner that minimizes the generation of such wastes and complies with all applicable Federal, State, and local environmental, safety, and beslth laws and regulations and DOE requirements.

The FB-Line Waste Management Program, as described in Procedure Manual S1-1-1, Item 7.01, "FB-Line Program Waste Minimization Plan (U)", is based on Procedure Manual is, "Waste Acceptance Criteria Manual (U)", and Procedure Manual 3Q. Procedure Manual is covers solid waste generated by the facility. Procedure Manual $3 Q$ covers air and water emissions and hazardous waste management

\subsection{Equipment Maintenance}

The FB-Line Equipment Maintenance Program, as described in Procedure Manuals SS22.1, "Senarations Maintenance Administrative Procedures Manual (U)" and 1Q10-3, "Separations En ingineering Quality Support Procedures Manual (U)", requires planned and systematic actions to preserve and promptly restore the operability, reliability, and availability of, or to prevent failure of, facility structures, systems and components. The program is based on a graded approach to maintenance and includes the following categories of maintenance activities:
a. Contective Maintenance
b. Modifications
c. Additions
d. Administrative orders
e. Technical specification surveillances
f. Periodic maintenance 
g. Planned maintenance

h. Predictive maintenance

i. Operaing services

j. Temporary modifications.

\subsection{Work Controt}

The FB-Line Work Control program, as defined in Procedure Manual SS22.2, "Separations Maintenance Work Control Procedures Manual (U)", provides a methodology for safely and efficiently identifying, managing, tracking, and documenting maintenance activities using an administrative control system that details the work process, from task identification through the documentation of a completed maintenance activity. This administrative control system uses a graded appraach (based upon functional classification) to maintenance activities, and includes:
a. Work identification
b. Wotk item validation
c. Work package preparation
d. Pre-work review and approval
e. Staging
f. Scheduling
g. Coortination and release
h. Wark order performance
i. Work completion and retest
j. Post-work review and documentation.

\subsection{Conduct of Operations}

The FB-Line Conduct of Operations program implements DOE Order 5480.19 through Procedure Manual 2S. This manual is the single site document which lists the Conduct of Operations requirements for each division and facility. Facility operations and support personnel are responsible for knowing and adhering to the requirements contained in this manual including any facility-specific use of a graded approach and approved deviations. 
WSAC-RP-so-1102 DU Rew. 0, Pago 30

\subsection{Performance Indicators}

The following are some of the performance indicators used to ensure compliance with applicable safety goals and requirements:

a. The Savannah River Site Environmental Report

b. The Savannah River Site Radiological Peformance Report

c. The Savannah River Site Annual Safety Appraisal Reports.

\subsection{OPERATING ENVELOPE}

The safety envelope for FB-Line is defined by the WSRC hazard and accident analyses and is maintained through the safety management programs and the BIO requirements. Operation within this envelope is analyzed and demonstrated in the authorization basis documents. These documents are described in Section 4.0 of this BIO, and currently address processing for Pu solution from F-Canyon, process residues, and offsite scrap. These documents also address storage of Mk 42 Scrap.

The OSR and TS, along with the additional controls identified in this BIO, provide limits and controls that ensure operation within the operating envelope. Table 8F documents the SAR requirements, OSR limits, TS limits, Safety-Related systems, Administrative Controls and Design Fearures credited for each dominant accident identified in the PHA and the FB-Line SAR.

For proposed activities that arise after issuance of this BIO, the USQ process will provide the mechanism for demonstrating that new initiatives remain within the operating envelope.

\subsection{SAFETY EVALUATION}

\subsection{Facility Categorization and Hazard Identification}

The hazard category of a facility is used in determining the level of analysis and. documentation required to define the Authorization Basis ope aing the facility. The method to determine a facility hazand category is given in DOE Standard DOE-STD-1027. 92 (Reference 1). In order to apply this method, the type and quantity of hazardous material expected to be present within the facility must be established.

For FB-Line, the significant hazands to workers and the public are the result of radioactive material and chemicals. Tables 8.A and 8.B provide information regarding the amount of radiasctive mrterial that could be present in FB-Line at any time. The maximum amount is $6.2 \mathrm{E}+06$ Curies at the isotopic distribution of Table 8.A. This value is calculated by using the maximum process inventories based on NCSS limits as summarized in Reference 6 and the specific activity from the SAR Actual operating limits are generally well below these values, and extensive management and programmatic safety involvement would be required to approach these values for some unforeseen reason. The ${ }^{239}$ Pu content fraction of this total alone establishes FB-Line as a Category 2 facility in that it exceeds the threshold of $900 \mathrm{gm} 239 \mathrm{Pu}$ as stated in Reference 1. 


\section{FB-Line Isotopics, from SAR}

\begin{tabular}{ll} 
Nuclide & $\begin{array}{l}\text { Isotopic Curie } \\
\text { Fraction }\end{array}$ \\
\hline Pu-238 & $1.38 \mathrm{E}-03$ \\
$\mathrm{Pu}-239$ & $6.65 \mathrm{E}-02$ \\
$\mathrm{Pu}-240$ & $1.49 \mathrm{E}-02$ \\
$\mathrm{Pu}-241$ & $9.17 \mathrm{E}-01$ \\
$\mathrm{Pu}-242$ & $1.15 \mathrm{E}-06$ \\
Total & $\mathbf{1 . 0 0 E}+00$ \\
\hline
\end{tabular}

Table 8.B

FB-Line Process Area NCSS Maximum Permissible Inventories

\begin{tabular}{|c|c|}
\hline $\begin{array}{l}\text { Process Area/Cabined } \\
\text { System }\end{array}$ & $\begin{array}{l}\text { Maximum Inventory } \\
\text { (kg of } \mathrm{Pu})\end{array}$ \\
\hline Cation Exchange. & 110.8 \\
\hline $\begin{array}{l}\text { Concentrate Feed and Flush } \\
\text { Adjustment }\end{array}$ & 10.8 \\
\hline Precipitation and Filtration & 92.5 \\
\hline Mechanical Line & 125.3 \\
\hline Recovery & 49.4 \\
\hline $\begin{array}{l}\text { Solution Transfer Vacuum } \\
\text { System }\end{array}$ & 12.14 \\
\hline - & \\
\hline Waste Handling & 114.47 \\
\hline NDA Room & 72 \\
\hline Miscellaneous & 1273 \\
\hline
\end{tabular}

Table 8.C provides capacities of tanks used to make up and store liquid chemicals used in FB-Line. The tanks listed transfer liquids to smaller head tanks which are used to feed process vessels. Information on the type of chemicals used in FB-Line and their physical forms is presented in Table 8.D. 
Table 8.C

FB-Line Cold Feed Tank Capacities

\begin{tabular}{lclc}
\hline Make-up Tank & $\begin{array}{c}\text { Approximate } \\
\text { Capacity, liters }\end{array}$ & Make-up Tank & $\begin{array}{c}\text { Approximate } \\
\text { Capacity, liters }\end{array}$ \\
\hline P-1A, B & 550 & P-12 & 61 \\
P-3 & 1211 & P-13 & 42 \\
P-4A, B & 318 & P-15 & 42 \\
P-5A, B & 160 & P-16A, B & 42 \\
P-6A, B & 250 & P-17 & 575 \\
P-7 & 250 & P-18 & 120 \\
P-8 & 255 & P-19A, B & 113 \\
P-8A & 770 & P-20 & 27 \\
P-9 & 200 & P-21A, B & 64 \\
P-10 & 1014 & P-22 & 660 \\
P-11 & 61 & & \\
\hline
\end{tabular}

Table 8.D

Chemicals Used in FB-Line Processing

\section{Chemical :}

Activated Ahumina

Aluminum Nitrate Nonahydrate

Argon

Ascortic Acid

Boric Acid

Calcium

Calcium Fluaride

Ferrous Sulfamate

Hydroxylamine Nitrate

Hydrofluoric Acid

Ion Exchange Resin

Nitric Acid

Magnesium Nyida

Nitrogen

Nitrogen

Oxygen

Soda Ash

Sodium Hydroxide

Sodium Nitrite

Sodium Sulfise

Sulfamic Aaid

Sulfuric Acid
Pellets

Liquid

Compressed gas

Solid cirystals

Crystalline powder

Granulated meal

Solid crystals

Liquid

Liquid

Liquid

Resin

Liquid

Sand and crucibles

Compressed gas

Cryogenic liquid

Compressed gas

Powder

Liquid

Solid crystals

Crystalline powder

Solid crystals

Liquid

a. All chemicals free of radioectivity. 
The potential effect of FB-Line radiological and chemical hazards on workers and the public can be divided into two categories - effects from normal operations and the postulated effect of potential accidents.

The impact of normal operations of FB-Line to the environment and the public is negligible. The SRS Environmental Report for 1989, WSRC-DM-90-60, Volume 1, summarizes the impact of 1989 SRS normal operations on the offsite environment and to the public. The 1989 report is referenced to reflect a recent time period during which FBLine was operating. The report concludes that the annual maximum dose from all SRS releases (not just FB-Line) for all exposure pathways was $0.61 \mathrm{mrem}$, as compared to the limit of 100 mrem (as specified in DOE Order 5400.5). Nonradiological atmospheric emissions were within applicable standards during 1989.

The impact of potential accidents is discussed in detail in Section 8.3. The accident evaluation in this BIO is based on the SAR for FB-Line, and a PHA. The dominant accidents for the facility, their relative frequency and consequence, and their degree of risk (i.e., Scenario Class) are given in Table 8.E.

\subsection{Hazard Analysis and Accident Categorization}

\subsubsection{Hazards Analysis}

\subsubsection{PHA Method}

A PHA was completed in May, 1994, for FB-Line, under the direction of DOE Headquarters (DOE-HQ). A team of WSRC personnel from FB!Line and DOE-HQ personnel was assembled to perform the PHA and document the results. The PHA represents a team exercise to identify significant radiological and chemical hazards associated with FB-Line. Frequencies and consequences were estimated in a semiquantitative manner for the accidents identified affecting the public or co-located worker. Accidents identified affecting the facility worker were treated qualitatively. For both cases, existing safety documentation and information were used to the extent possible.

After identification, the accident scenarios were binned into one of three frequency categories and one of three consequence categories, for a final risk class (called Scenario Classes) ranging from I to IV, with I being those with the highest risk and IV being those with the lowest risk In addition to categorizing the accidents, the team idenaisin engincered systems, structures, components, controls, or procedures that are in place to prevent or mitigate the accidents. Table 8F summarizes the significant results of the PHA including the prevention and mitigation characteristics for the process accidents identified in the PHAYSAR. The principal rocommendations in Section 4.0 of the PHA are addressed in Table 8.F and Section 8.3.2. The recommended enbancement in Section 4.4 of the PHA (compliance with FHA recommendations) will be addressed by facility management and documented in approved CSAs prior to declaration of readines for restart (C).

The purpose of the PHA was to identify dominant accident scenarios and the safeguards in place to protect against them. The process by which scenarios were identified as dominant was largely qualitative, besed on a review of the deviations by the PHA Team to determine a set of scenarios spanning a spectrum of accident types (fires, spills, explosions, etc.) having the potential to present significant radiological or non-radiological consequences to personnel inside the facility, onsite, and offsite. To chancterize the potential for consequences in a manner appropriate to the level of effort required for a BIO document, the identification generally focused on the event presenting the largest consequences to the

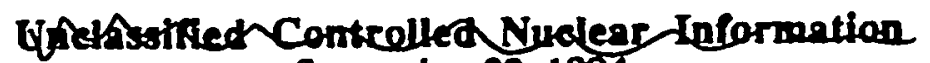
September 23, 1994 


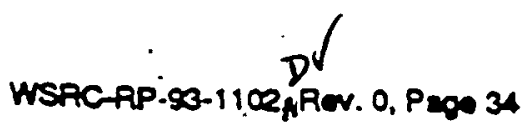

affected receptors. This does not necessarily mean that the accident scenarios are valid for sibuations involving other process equipment and smaller source terms.

The technique used in the PHA accident analysis was an adaptation of the Hazard and Operability Review (HazOp) technique that was first developed for use in the chemical process industries. The facility in question is split into nodes, which usually are lengths of pipework between major items of equipment or major vessels. Then the causes and consequences of deviations from normal operation, such as high flow/temperanure/pressure, low flow/temperanure/pressure, no flow, reverse flow, high or low level, etc. are investigated. If a cause is identified that leads to significant consequences, existing safeguards are discussed. If these safeguards are not adequate, design or procedural changes or additional analysis may be recommended. Details on the hazard analysis process for FB-Line may be found in the PHA.

Estimates of frequencies and consequences for the dominant accidents identified in the process described above were refined, where necessary, through further research and consideration of additional information such as airborne relesse fractions, respinble fractions, initiating events, preventive and mitigative feanures, and dispersion mechanisms. Additional supporting information for the PHA analyses was developed using a range of qualitative and semi-quantitative techniques, ranging from engineering judgment to event tree development.

The accident scenarios thought to bound the risk at FB-Line are summarized in the PHA. These scenarios are as follows:

1. Inadvertent Criticality

2. Ion Exchange Column Explosion

3. Propagated Fire

4. Worker Exposure Due to Air Reversal

Section 8.2.2, Accident Categorization, describes the "binning" of these scenarios into classes which indicate the relative risk associated with these scenarios. Only the accident scenarios binned as Scenario Class I and II are considered dominant acciden: an givan detailed discussion in this BIO.

\subsubsection{SAR Method}

The purpose of the SAR is to describe the facility and equipment operation and document the principal andyses made to determine that the facility can be operated without undue risk to the public. It identifies potential hazards and parameters affecting facility safery and determines with reasonable assurance that the facility has the capacity for preventing accidents or mitigating their effects sufficiently to preclude undue risks to the health and safety of the public and co-located workers. It also provides technical information needed to define the boundary between acceptable and unacceptable conditions.

\subsection{Conversion Factors}

ICRP 2 Dose Conversion Factors were used in SAR consequence analyses, as opposed to the most current ICRP 30 Dose Conversion Factors. An increase of risk caused by. ICRP 30 dose conversion factors will occur, but sample calculations show that the resulting increased risk is still within the guidelines that have been documented by DOE, NRC, and

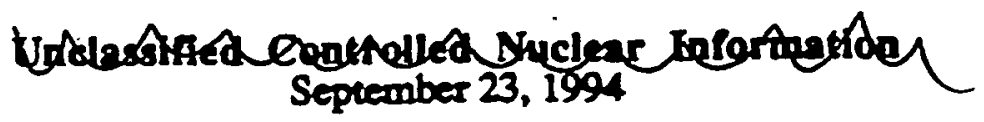


WSRC. Section 8.3 of this BIO gives descriptions of accidents analyzed in the SAR, and the estimated effect of ICRP 30 conversion factors, as well as ICRP 30 consequences for bounding accidents (see section 8.2.1.2.2). The ICRP 2 models for lung, bone and other organs were defined in 1959. The ICRP 30 (1979) models account for dose to organs (target) from beta- or gamma-emitting nuclides deposited in neighboring (source) organs. This added complexity accounts for no change in dose if the nuclide is an alpha emitter, but may be quite large for some organs if the nuclide is a gamma emitter. Dose calculations for mixed fission products generally yield higher results with the ICRP 30 models than with the earlier models. For this document, the dose due to weapons grade Pu (isotopes 238, $239,240,241$, and 242) in both the ICRP 2 and ICRP 30 models were compared, and the weighted effect (by isotopic fraction) was an increase by a factor of nearly seven for all accidents except criticality. Criticality doses are dominated by the volatile fission products, which. when compared in the same manner, increase by a factor of less than three. These factors can be conservatively applied to any accident analyzed in the SAR. For the bounding accidents, doses were calculated using AXAIR89Q, which includes upgrades to meteorology and population databases, and therefore do not reflect the simplified factors of seven and three.

\subsection{Source Terms}

Existing risks in the SAR reflect nominal batch sizes and are besed on typical Pu isotopic composition for the material that was being processed in the facility at the time the SAR was written. Specific activities used in dose consequence calculations were based on halflives for the various $\mathrm{Pu}$ isotopes published in Reference 7. Source terms for accident consequence analysis were based on the energetics of the accident. Release fractions are based on the material being in the form of liquids and finely divided solids, which is conservative, given that in many cases, some, if not all of the material is metal. For simplicity, accidents were grouped into three potential categories: high energetic, medium energetic, and low energetic. A high energetic event is defined in the SAR as one which will destroy both the first and second confinement barriers (e. g., vessel and glovebox), allowing radioactivity to reach the process room directly. Given that no high energetic accidents were identified for the FB-Line operation, a single batch of material was a logical source term for all risk analyses.

Current USQ requirements show the need for a bounding consequence analysis in each of 3 frequency categories. Therefore, for this document the source term for five bounding accidents is conservatively based on maximum allowable inventories, as defined in the NCSS. Five accidents, rather than three, are analyzed in this manner so that a comparison can be made among accidents of different types within the same frequency category. The maximum inventories, allowed by NCSS under special conditions, are significantly above the normal operating limits. This method for determining the source term is applied to the processing inventory in the analyses discussed in this report and the FB-Line Vault inventory, is well, for the earthquake analysis. Although the vaults contain a variety of different materials with different isotopic compositions, this assumed weapons grade isotopic composition was compared to the material contained in the vaults and to material postulated to be in the vaults in the near future and found to be conservative (Reference 8). The build-up of $241 \mathrm{Am}$ was considered in this comparison. In addition, these bounding consequence analyses were analyzed using the updated AXAIR89Q dose code, rather than simply multiplied by a factor to account for differences in ICRP 2 and ICRP 30. Table 8.B shows the maximum inventories by Process Area/CabinetSystem.

Existing material has been analyzed according to operating procedures and found to be within the scope of the Authorization Basis, and any material to be stored or processed in 


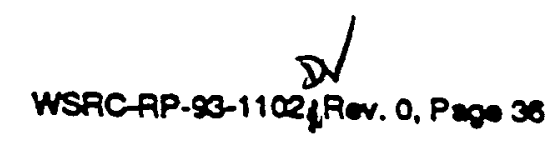

the facility in the future that is not within prescribed composition limits will be analyzed under the USQ process and the new configuration control system to evaluate the risk

\subsection{Population Data Base}

A population database for 1980 was used in the SAR as opposed to the more current 1989 database, which reflects an increase in both onsite and offsite populations. This difference does not affect the maximum individual risk, but depending on which sector is "worst" for a particular accident scenario, the onsite population risk could increase by a factor of approximately two.

The maximum onsite population dose due to a single accident, as documented in the SAR, was 2.78 person-rem, for criticality, with a frequency of once per 7400 years. Accounting for the conversion to ICRP 30, this would increase by a factor of 3 to 8.34 person-rem. With the new population database, the risk could approximately double to 16.7 personrem.

\subsection{Dose Recipients}

The existing SAR evaluates 3 dose recipients. These recipients include the onsite population, offsite population, and the maximum exposed individual offsite. SARs prepared to SROM 5480.5-1 (Reference 9) evaluate 7 dose recipients. The 4 additional groups are:

- Facility operator at the site of the accident

- Personnel within adjacent areas within the facility

- Maximally exposed individuals within the area (excluding the initiating facility)

- Area population (excluding the initiating facility).

The maximum individual offsite is the only recipient for which DOE has criteria on which to judge the acceprability of accidental radiation dose. An estimate of the dose for the colocated worker 640 meters from the stack was made for the bounding accidents. Using $50 \%$ metrorology, this co-located worker could expect a dose (ICRP 30) of about $5.21 \mathrm{rem}$ due to a propagated fire with maximum inventory, $260 \mathrm{mrem}$ due to a criticality with $1 E+19$ fissions, and 343 mrerif due to a vi. $2 \mathrm{~g}$ earthquake with maximum inventory. Given the low frequency for such events WSRC considers this to be an acceptable risk.

\subsubsection{Accident Categorization}

The accident scenarios from both the SAR and the PHA have been evaluated in terms of a "Risk Marrix" to place the consequences and frequencies of accidents into broad bins to aid 
in comparing the relative risks of the accidents. This matrix appears below:

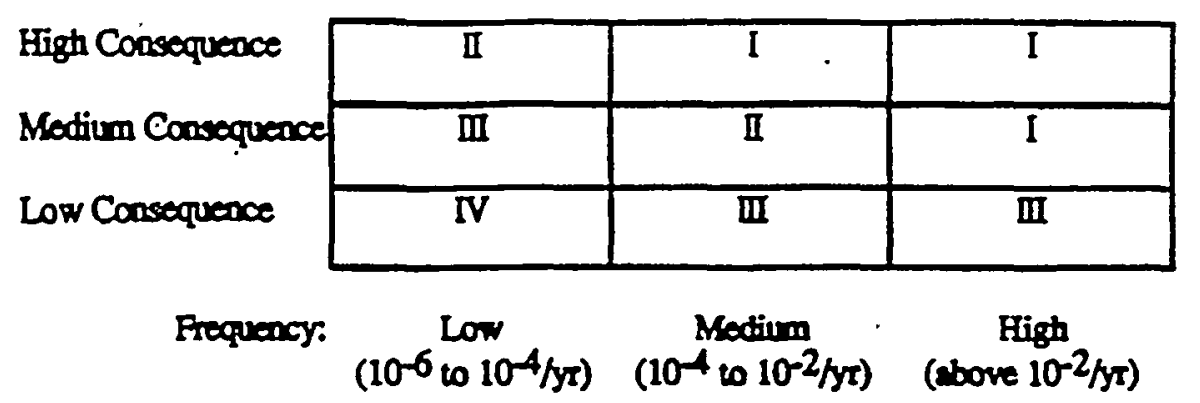

The Roman numerals in the table represent Scenario Classes, which are defined as follows:

Scenario Class IV - Negligible

Scenario Class III - Marginal

Scenario Class II - Serious

Scenario Class I - Major

The consequence levels corresponding to the high, medium and low consequence bins are shown in the matrices below, the first for radiological consequences and the second for chemical accident consequence levels :

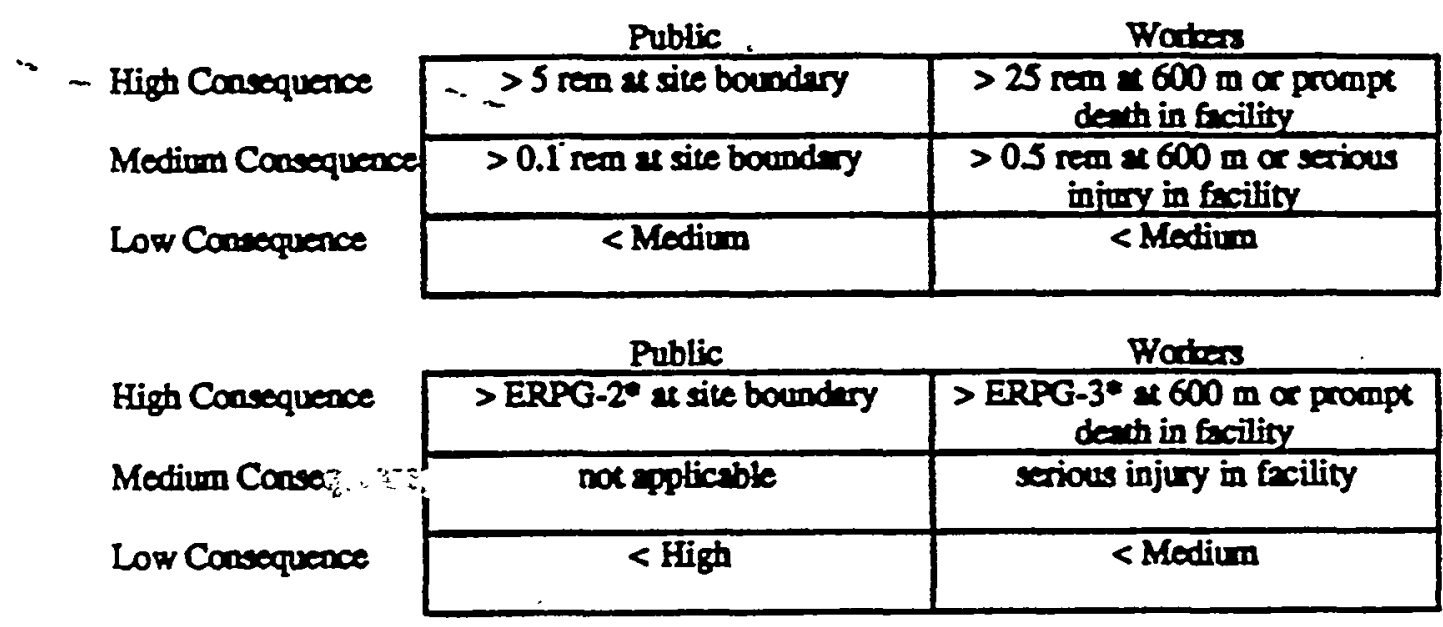

* ERPG-2 and-3 ure Emergency Response Planning Guidelines as stated in DOE Standard DOE-STD-3011-94.

It is noted that the co-located receptor location is $600 \mathrm{~m}$ in the DOE guidance (Reference $10)$, whereas the co-located receptor location that was used in this analysis is $640 \mathrm{~m}$. This is due to the existing standard at SRS of using the dose at $640 \mathrm{~m}$ for evaluation purposes.

Table 8.E contains a summary of the results of the binning process. Consequences in this table are identified in terms of the impact to facility workers, co-located workers, and the public, as applicable. The Scenario Class I and II accident scenarios are described in Section 8.3.2. 


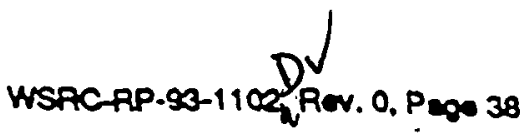

Table 8.E

Summary Table of Results of Risk Matrix Binning for FB-Line Operations

\begin{tabular}{|c|c|c|c|c|c|}
\hline SCENARY & CONSEQUENCE & FREQUENCY & $\begin{array}{l}\text { SCENARIO } \\
\text { CLASS }\end{array}$ & $\begin{array}{l}\text { RECEPTOR } \\
\text { (Note 1) }\end{array}$ & $\begin{array}{l}\text { SOURCE } \\
\text { DOCUMENT }\end{array}$ \\
\hline $\begin{array}{l}\text { Inadvertore } \\
\text { Criticality }\end{array}$ & High & Motium & I & Fecility Wartar & SAR \\
\hline $\begin{array}{l}\text { Inodvarear } \\
\text { Criticality }\end{array}$ & Low & Medinm & III & $\begin{array}{l}\text { Colloced } \\
\text { Worter, Public }\end{array}$ & $\mathrm{BD}$ \\
\hline $\begin{array}{l}\text { Ioa Exchenge } \\
\text { Column Explosion }\end{array}$ & High & Modium & I & Fecility Wortex & PHA \\
\hline $\begin{array}{l}\text { Ion Exchenge } \\
\text { Column Explocion }\end{array}$ & Low & Modinm & III & $\begin{array}{c}\text { Collowed } \\
\text { Water. Public }\end{array}$ & PHA \\
\hline $\begin{array}{l}\text { Single Level } \\
\text { Propagated Fire }\end{array}$ & Metium & Medium & II & $\begin{array}{l}\text { Collocand } \\
\text { Watter, Public }\end{array}$ & PHA \\
\hline Propagated Fire & Modium & Low & III & $\begin{array}{l}\text { Collocaled } \\
\text { Water, Public }\end{array}$ & $\mathrm{BD}$ \\
\hline Air Reversel & Low & High & III & Fxility Worter & PHASAR \\
\hline $\begin{array}{l}\text { Exthqusine } \\
=2\end{array}$ & Low & Modium & III & $\begin{array}{l}\text { Co-Locand } \\
\text { Warter, Public }\end{array}$ & BD \\
\hline $\begin{array}{l}\text { Medium Energetic } \\
\text { Eveas }\end{array}$ & Low a: & Motion & III & Public & SAR \\
\hline $\begin{array}{l}\text { Low Energetic } \\
\text { Event }\end{array}$ & Low & High & III & Public & SARBIO \\
\hline
\end{tabular}

Note 1 - The co-located warber is $640 \mathrm{~m}$ away from the relesse point.

\subsection{Accident Analysis}

\subsubsection{Dominant Accidents}

A summary of the operating risks for FB-Line, documented in the PHA, the SAR, and this BIO, is iocluded in Table 8E. The "bins" selected for the accidents listed in the table are based on the meximum consequence value calculated and the corresponding frequency.

\subsubsection{Dominant Accident Scenario Descriptions}

This section presents descriptions of the dominant accident scenarios (ie., Scenario Class I and $\mathrm{II}$ ) reported in Table 8.E. A comprehensive presentation of specific safeguards for these accidents and detail on how these safeguands are preserved can be found in Table 8.F. These safeguards include items such as applicable SAR requirements, OSR, TS, identification of Safery-Related equipment, ACs, and DFs. Table 8.F also clessifies the safeguards for these accidents as either preventors or mitigators. Each accident scenario discussion provided below describes the sequence of failures that must occur to cause a release, the assumptions incorporated in characterization of the release; the consequence, frequency and accident scenario classification; and provides a description of the preventive 
and mitigative features (safeguards) relied upon to protect against the accident. Safeguards added or recognized as a result of a scenario evaluation are specifically identified as ACs or DFs. For Scenario Class I accidents, an explanation of frequency and/or consequence reduction is provided from the original PHA/SAR scenario.

The Scenario Class III accidents listed in Table 8.E are not explicitly described in this section because they are not considered to be dominant accident scenarios. For more information on these accident scenarios, see the PHA, the SAR, or Section 8.3.3 and 8.3.4 of this BIO. Where BIO is listed as the source document, the new analyses upon which classification is based are those analyses described herein as having been performed using the new updated AXAIR89Q source code.

\subsubsection{Inadvertent Criticality}

The potential for insdvertent criticality was examined extensively in the PHA and has been a key safety concem FB-Line operators have managed for decades. The controls and safeguards against inadvertent criticality generally consist of geometrical configurations that limit the potential for criticality in vessels, and/or limits on the concentrations of fissile materials in solutions, and/or limits on the total amount of fissile materials in any one vessel, and/or limits on the quantity of solid fissile material in any one area.

These general safeguards are implemented throughout FB-Line by specific equipment such as favorable geometry process vessels; precipitator neutron monitors to prevent excessive $\mathrm{Pu}$ accumulation; and sample and waste assay equipment.

Inadvertent criticality was analyzed as a.credible and bounding accident in the SAR. Estimated number of fissions produced as a result of a Pu solution criticality (the most likely criticality scenario) w̄as determined by a statistical analysis of historical criticality accidents. The mean number of fissions was determined to be $2 \mathrm{E}+18$, and this was the value used in developing the source term for a criticality socident in FB-Line. The release percentage for a medium energetic event, 0.02\%, (Reference 11) is applied to the typical batch size of one vessel, and this amount of $\mathrm{Pu}$ and nonvolatile fission products was assumed released to the sand filter (99.51\% efficient). In addition, $100 \%$ of the volatile fission products are assumed to be released, with no filtration provided by the sand filter. The result was a release to the environment of $4.8 \mathrm{E}+4$ curies of volatile fission products and 0.047 curies of nonvolatile fission products plus $\mathrm{Pu}$. The resulting dose to the maximally exposed offsite individual was $1.6 \mathrm{mrem}$ (ICRP 2 visises). "he same accident, factored up to account for ICRP 30 dose values, would be 3 times greater in consequence. or 4.8 mrem. The reason for the factor of three, versus the factor of seven used in all other consequence analyses, is due to the dominating effect of the volatile fission. products on the final weighted average dose. Volatile fission products did not change as significantly as Pu in the ICRP upprade from version 2 to version 30.

For the new bounding criticality accident, the source term was based on a maximum number of fissions, as recommended in NUREG Guide 3.34 (1E+19). The typical batch size for one vessel was used for calculation of the Pu release, as was done in the SAR. Use of the maximum permissible inventory per NCSS limits would not have affected the consequence analysis, since volatile fission products (which are not filtered out and are determined by number of fissions rather than batch size) dominare the release, which is analyzed using the updated AXAIR89Q dose code. This maximum number of fissions is considered to be bounding for both solution and metal criticalities. The result was a dose to the maximally exposed offsite individual of $7 \mathrm{mrem}$ (ICRP 30). Co-located workers, located 640 meters from the stack, using 509 meteorology, could expect a dose of about 260 mrem (ICRP 30) from this criticality accident scenario.

Unctassiffed Coutrofted Nuctern fuformatior September 23, 1994 
For the FB-Line SAR, the sequence of events that can lead to an accidental criticality was modeled in a fault tree. It is believed that this fault tree accurately bounds the full spectrum of possible accidents, including both solution and metal criticalities. Input for the basic events in the fault tree was extracted from the 200 Area Fault Tree Data Bank, which contains over 250,000 entries, and spans over 20 years of operation at SRS. The use of this facility specific data allows for inclusion of many types of failures, including those due to aging, and also allows for trend analyses, as documented in Reference 12 . It may not, however, consider all common mode failures. Use of the 200 Area Data Bank, in conjunction with estimates on human reliability, results in an estimated frequency of a criticality accident of 1.4E-04 per year or once every 7400 years, as documented in Reference 13. As with most fault tree estimates, there is uncertainty in the estimated values.

During a Readiness Self Assessment for restart of FB-Line, it was recognized that a need existed to re-examine controls for hydrogen dilution in FB-Line process vessels. Subsequent investigation revealed that enough hydrogen could be generated and could accumulate with time in the vapor space of FB-Line process vessels to potentially exceed the lower flammability limit (LFL). Structural analyses and nuclear criticality safety studies have concluded that geometrically favorable vessels can be sufficiently deformed huring a hydrogen deflagration to cause a nuclear criticality based on existing mass limits. A fault tree analysis was performed (Reference 14) that showed the additional frequency. of criticality due to hydrogen deflagration in FB-Line is $4.47 \mathrm{E}-04$ per year for a new overall frequency of 5.9E-04 per year or once every 1700 years. As a result of this analyșis, the facility has identified the hydrogen dilution purge systems as Safety-Related equipment for inclusion into Procedure Manual S1-1-1, Item 2.01 (See Section 8.5 for a description of this procedure).

Añ additional criticality concern for FB-Line is the sprinkler systems to be installed in the facility. The possibility that the sprinkler water may incrense the likelihood of an inadvertent criticality and/or violate existing assumptions reganding the criticality safety of the facility has been noted. In light of this concern, the facility will perform a study to determine the impact of the sprinklers prior to their installation (C).

NIMs are required where needed in accordance with DOE Order 5480.24 requirements. The monitors have historically been considered as very important to safety, and under recent guidelines are being defined as a Snfery-Polated system, with rigorous surveillance requirements, as defined in the OSR and NTM TS. Personnel are periodically trained in the proper response to a NIM alarm, and are assumed to evacuate immediately when an alarm is activated.

The SAR ascumed that in the event of a nuclear criticality accident, the NDMs would allow facility personnel to evacuate before the second burst However, if multiple bursts were considered, only the impact on in-facility personnel would increase (consequence due to released fission products already assumes a total number of curies over an 8 bour period). In the SAR, an estimate was made for the number of in-facility worker fatalities that would occur as a result of a criticality in FB-Line. In Reference 13, estimates of typical facility occupancy were transposed to facility floor plans, and then, circles with radii of 23 feet (unshielded distance from an isotropically emitting radiation source of $2 E+17$ fissions [first burst] that would produce an instantaneous dose of about 500 rad) were drawn from analyzed sectors in the fault tree where a criticality could occur. The number of workers within the circles were counted as assumed fatalities, and divided by the number of sectors for an average consequence of 4 fatalities per criticality. As part of the startup requirements, evacuation of facility personnel was verified to take less than 103 seconds 
(Reference 15). It is possible that multiple bursts could occur before complete evacuation of the facility can take place. However, as stated in Reference 16, the time between bursts coupled with typical evacuation speed should be ample to assure that no worker is exposed to appreciably more than one burst. Given the low probability of occurrence of a second burst, and the fact that no credit is taken for self absorption or shielding, the estimate of 4 fatalities per criticality is considered to be quite conservative.

It is WSRCs position that the SAR estimate of worker fatalities due to a criticality, which uses a mean number of fissions from the first burst for historical solution criticalities, is conservatively realistic, given that of the 8 process accidents and 5 critical experiment accidents recorded in DOENNCT-04 (A Review of Criticality Accidents, March 1989), none had a spike yield over $6 E+17$, only one even bad a tonal yield over $3 E+18$, and only two of the accidents resulted in fatalities (single esch). The largest sccident, with a total yieid of $4 E+19$ and 2 spike of $1 E+17$, occurred in 25000 gallon tank with $35 \mathrm{~kg}$ of uranium, which is much larget than any FB-Line scenario. Bare and reflected metal systems had even lower yields. In addition, for most criticality accident scenarios in FB-Line, a second burst is unlikely to occur. This is due to the fact that the fault tree analysis concludes that the accidents most likely to occur either involve solid fissile material (which will disassemble and have only a single burst) or involve a solution that has been mistakenly collected in a temporary, nonfavorable geometry container such as a bucket, plastic bag, etc. In the solution scenario, either the container would not survive the criticality event, or the solution would quickly become subcritical due to rapid boil off of moderator.

At the request of the Office of Nuclear Safety, a nuclear criticality expert at Los Alamos National Laboratory provided an independent review of the criticality assumptions and analyses pertaining to WSRC's FB-Line Operations. The scope of his review (Reference 16) included site specific safety documentation, site visits, and published documents on criticality accidents, and supparts WSRC's position that existing analyses are conservative.

Although criticality is classified as a Class I event for the facility worker besed on its frequency as stated in the SAR and modified in this BIO, WSRC does nor feel that any additional measures and/or limits are practical, nor necessary that reduce criticality frequency or consequence to Scenario Class II or lower. This position is supported by the above described review, as well as the conclusion of the PHA team that criticality is a low frequency event, resulting in its classification as a Class II scenario, and takes into consideration the Nuclear Criticality Safety Program described in Section 6.3.7.

\subsubsection{Ion Exchange Column Explosion}

FB-Line contains 2 anion exchange columns and 4 cation exchrnge columns. Many process specific enginering and administrative controls are in place to assure the resin is kept in a safe configuration.

Ion exchange resin, specifically nitrated anion exchange resin, has been known to breakdown with the evolution of combustible gases and pressures rupturing equipment causing significant equipment damage. Several incidents of anion exchange column ruptures have occurred across the DOE Complex and worid wide with similar causal factors. The causal factors involved with the anion exchange incidents all have root causes which are the same. These root causes have been verified through extensive laboratory testing performed over the past 30 years to be the chief contributors to ion exchange column accidents and therefore are the most pertinent operational parameters to control.

The chief parameters responsible for maintaining safe ion exchange resin operation are nitric acid concentration of solutions in contact with the resin, heat load on the resin.

- Unchassiffed-Gontrotted Nuelesr Information-

September 23, 1994 


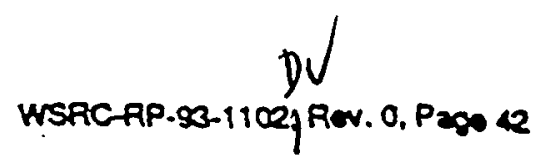

maintaining liquid surrounding the resin, pressure build-up negation, and resin radiation dose limitation. Controlling these parameters has been proven to assure safe ion exchange column operation. Contrarily, the absence of control on individual parameters does not guarantee the occurrence of an adverse event. These events initiate only from a combination of out of control parameters, not from a single out of control perameter.

FB-Line employs engineering controls in the resin process to assure these chief parameters are maintained. Both anion and cation resin processes employ a "loop-seal" design in the process piping which ensures the resin is covered with liquid at all times. Having a liquid blanket around the resin is important as it provides a very effective heat sink for removing the docay beat generated from the absorbed $\mathrm{Pu}$ and not allowing the resin temperature to increase. Another significant engineering control on the resin processes is the ever open vent. This ever open vent system provides a pressure sink to absorb gases which may be generated during a resin incident thus preventing pressure induced tempernture increases and vessel pressurization. Typically, these Engineering controls are sufficient to guarantece a safe condition of the resin. However, to further ensure the safe condition of the resin; adtitional administrative controls are inplementod.

The administrative controls employed by FB-Line include items which support the Engineering controls and additional Authorization Basis level requirements for radiation exposure limits on the resin, time limits for leaving a column in a losded state, maximum nitric acid concentration allowed in contact with the resin, and resin temperzoure. By controlling these additional parameters administratively, in association with the Enginering controls, safe operation of the ion exchange processes can be assured.

In response to Recommendation 4.0 in the PHA, the safety envelope for this scenario is presented in Table 8.F. The PHA classified this event as a Class I scenario on the basis of a fault tree performed in 1987, which calculated a frequency of $1.7 \mathrm{E}-4 / \mathrm{yr}$ for anion and 4.1E-11/yr for cation, and a "high spot" estimate of consequences, which took no credit for the cabinet's ability to contain the explosion. The letter that presented the estimate of consequences suggests that the estimate could be improved by considering the effectiveness of the cabinet in containing an explosion.

A more thorough analysis will be performed within 12 months after startup or the explosion and its effect on existing confinement. WSRC commita. sn provide other measures as necessary to prevent a fatality from occurring and reduce this event to Scenario Class $\mathbf{I}$ or lower (C). In performing the analysis of the ion exchange column explosion, mitigative structural feanures of the cabinets will be reviewed and included. It is suspected that specific structural features of the ion exchange equipment will significantly reduce the frequency of worker fatality.

Dose coasequences to facility workers are mitigated by the cabinets and cabinet and room exhaust ventilation systems which would continue to operate following an explosion, thereby reducing the concentration of radionuclides in the operating room air. The room exhaust ventilation system would also serve to prevent workers in other parts of the facility from being exposed.

\subsubsection{Propagated Fire}

The existing SAR analyzed a process fire scenario that was assumed to propagate through the building level with the highest typical Pu inventory present. This scenario is considered highly unlikely due to the administrative controls on transient combustibles and the presence of $\mathrm{few}$ initiators. The resulting release was 0.16 curies, with a dose to the maximally exposed offsite individual of 2.43 mrem (ICRP 2 values). Again, the same 
accident, factored up to account for ICRP 30 dose values, would be 7 times greater in consequence, or $17.0 \mathrm{mrem}$. It should be noted that over $99 \%$ of the curries released in the propagated fire scenario were the result of burning ion exchange resin. A release fraction of $2.5 \%$ was applied to the Pu contained on the burning resin, unlike the process fire scenario which uses a release fraction of $0.02 \%$.

The PHA also examined a fire that propagates through a single level, but assumed maximum NCSS inventories. The worst case fire considered by the PHA was a propagated fire on fifth level, which was assumed to occur at a frequency of 1.TE-4/yr. However, analyses available at the time of the PHA did not reflect the fact that the third and fourth level exhaust is not tied to the sand filter. A more recent analysis, which corroctly reflects third and fourth level filtration and assumes no vault involvement, has shown that the worst case is in fact a fire which propagates throughout the fourth level. The source term for a propagated fire on fourth level would be a 35.9 curie release. Analysis, using the updated AXAIR89Q dose code, resulted in 2 dose to the maximally exposed offsite individual of $2.23 \mathrm{rem}$ (ICRP 30). A co-located worker, located 640 meters from the stack, using 50\% meteorology, could expect a dose of about $2.95 \mathrm{rem}$ (ICRP 30). The SAR envisioned no plausible scenario for a propagated fire on fourth level; bowever, for the purposes of this BIO, the fifth level frequency is conservatively assumed. Thus, a single level propagated fire becomes the bounding accident for the middle frequency category.

The consequence analysis in the existing SAR for a propagated fire assumed typical processing, which would be a single batch of material in each unit opention. Additionally, the SAR assumed that a fire would not propagate from one level to the next. However, a bounding analysis would analyze the conservative scenario of maximum allowable inventory within a unit operation, which is allowed under current NCSS, and assume the fire could propagate from level to level. A study bas been conducted (Refereace 17) that concluded a propagated fire would not engulf the vaults or cause the nuclear material there to be dispersed. Assuming maximum NCSS inventories, with all parts of the facility involved with the exception of the vaults, with no credit taken for high efficiency particulare air (HEPA) filters (i.e., no filtration for 3rd and 4th levels and only sand filter filtration for 5th and 6th levels), the source term for a propagated fire would be a 53.6 curie release. Analysis, using the updated AXAIR89Q dose code, resulted in a dose to the maximally exposed offsite individual of $3.95 \mathrm{rem}$ (ICRP 30). A co-located -portrt, lnated 640 meters from the stack, using 50\% meteorology, could expect a dose of about $5.21 \mathrm{rem}$ (ICRP 30). The occurrence of fire that consumes the entire facility is conservatively assumed to be a factor of 10 less frequent than one which propagates throughout the fifth level as anslyzed in the SAR, given the fact that no fires have propagated beyond their room of origin. Although the current release values result in an acceptable risk versus DOE guidelines, the facility commits to complete the tie-in of third and fourth level exhausts to the sand niter by December 1995, in order to further reduce this risk (C). To further ensure that the vaults will not be breached during a fire, the facility commits before declaration of readiness for restart to complete computer modeling to predict temperatures during a worst case fire. Any upgrades deemed necessary to prevent fire propagation into the vaults will be provided on a schedule to be determined (C). Piping penetrations will be sealed by October 30, 1994, regardless of the results of the computer modeling (C). Other penetrations will be evaluated after computer modeling is complete. Until modeling and upgrades are complete, transient combustibles will be restricted in rooms toujacentw uev valuts.

A fire which propagates into a vault through an open door would result in a higher consequence than the bounding fire described above. In order to understand the dominant 


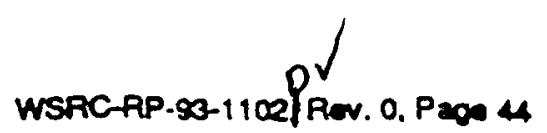

sequences that could lead to such an event, a fault tree was constructed and analyzed. Scenarios included in the tree were : 1) A fire starts near a NIM and grows to cause a false NIM alarm before propagating to the vault, 2) a "hot short" in a NIM unit that causes both a false alarm and leads to a propagated fire, and 3) a fire stars outside the vault and propagates into the vault through a door left open due to violation of the exiting procodure. The result of the fault tree analysis was a frequency of $6.8 \mathrm{E}-7 / \mathrm{yr}$, with the "hot short" scenario being dominant. The following are examples of some of the conservatism incorporated in the analysis: 1) All NDM "hot shorts" are assumed to result in false NIM alarms, 2) all NIM shorts are assumed to result in a fire large enough to propagate, 3) propagation potential for all NDMs was estimated based on the "worst case" NDM configuration, and 4) Datz from burning televisions and business machines with plastic and wood frames were used to estimate the heat output for a burning NMM, which has a metal base. Given the low frequency and the conservatisen in the estimate, further consequence analysis is not required. As a result of the fault tree analysis, an additional AC has been added to Table 8F to restrict combustibles from the vicinity of NIM units. The addition of an automatic door closing mochanism, as committed to in CSA SRS-DOE-5480.7-CSA225 , will further reduce the frequency of a fire propagating to the vault through an open door.

A seismically induced propagated fire is not considerod credible (Reference 19).

The consequence of a fire which propagates from F-Canyon into FB-Line is bounded by the multi-level propagated fire described above. Since the frequency of such 2 fire is expected to be less than the frequency of a propagated fire which originates in FB-Line, the risk is also bounded.

The safety envelope for the propagated fire scenario is presented in Table 8.F.

\subsubsection{Earthquake}

The process building and sand filter system were built to Class I construction (Reference 20) standards, and are expected to withstand a DBE (References $21,22,23,24)$. The SAR assumes they will remain intact, with localized damage, and provide confinement after a DBE. A DBE is defined as one with a ground acceleration of $0.2 \mathrm{~g}$, which corresponds approximately to a Modified Mercalli Scale VI: exthquice.

In 1989, the U.S. Army Corps of Engineers re-evaluated the results from an earthquake study performed for the 221-H Building by Engineering Decision Analysis Company (EDAC) and essentially agreed with the results, but had some recommendations. The recommendroions included a furcher evaluation to be completed on the facility to investigate the DBE seismic effects on non-structural items, including mechanical and electrical equipment and their systems. Based on these recommendations WSRC has developed a schedule for the re-evaluation of the 221-H Building to withstand 0.28 earthquake. This schedule includes the development of a static and dynamic model and includes structural and geotechnical analysis of the H-Canyon and surrounding facilities along with an analysis of the effect of localized structural failures. Since 221-F Building, including FB-Line is structurally similar to the 221-H Canyon Building, the analysis and results obtained for 221-H will be applied to the 221-F Building with appropriate justincations, as necessary (C).

An additional, limited scope structural analysis was performed to assess the F-Canyon's structural performance during and after earthquake events. (reference WSRC-TR-940248) The primary goal of this analysis was to assess if the structures wet code allowables when 
subjected to a ground acceleration of $0.2 \mathrm{~g}$ (DBE). If code allowables were not met, a "no collapse" evaluation would have to be performed with the input being the Blume spectrum scaled to a level of $0.3 \mathrm{~g}$.

Section 6 of the F-Canyon, including the FB-Line penthouse was selected for the analysis. This section was chosen because the structural details of the main structure and the penthouse are typical to a number of other sections and would be generally representative of the F-Canyon structure. This typical section is also critical under seismic load conditions due to its lack of shear walls and thus has a limitod ability to withstand seismic forces. As indicated in the analysis, several locations within the building did not meet ACI 349 code allowables for the $0.2 \mathrm{~g}$ Blume input, therefore, non-linear analyses were performed. The two non-linear hysteresis models (elasto-plastic and Takeda) were used with the single-degree-of-freedom (SDOF) system representing the globel behavior of the building to compute the dynamic response of the building to the $0.2 \mathrm{~g}$ and $0.3 \mathrm{~g}$ Blume input.

For the $0.2 \mathrm{~g}$ input, the results of the dynamic analyses indicate that both non-linear hysteresis models produce a maximum relative displacement of the SDOF system of about 2.3 inches, as compared to 2.0 inches predicted in the elastic SASSI (a System for the Analysis of Soil-Stucture Interaction) analysis. Both non-linear analyses indicate limited global non-linear behavior and the permanent displacements predicted are insignificant. For the $0.3 \mathrm{~g}$ input, the non-linear hysteresis models predict maximum relative displacement of less than 4 inches. The elasto-plastic hysteresis model results in a permanent displacement of the SDOF system of about 2 inches, which is less than $0.25 \%$ of the story height. The Takeda hysteresis model results in a permanent displacement of less than 1 inch.

$\because$ -

The analysis concluded Section 6 of the F-Canyon does nor meet ACI 349 code allowables for the DBE input. However, the localized non-linearities realized during the DBE event have limited global consequences. For the 0.38 enthquake, more extensive non-linear behavior is predicted, but given the areas that were critically examined in the analysis, the structure remains stable (i.e., it does not collapse) and shows joint rotation less than those specified in ACI 349.

Consequence analysis is based on 5E-6\% (Reference 11) of the total facility inventory becoming airborne, either through the ventilation system (if running) $\alpha$ through building cracks that may result from UiE WBE. The composite release fraction of SE-08 is consistent with more recent information on airborne release fractions from DOE-HDBK-3010-94 (1E-04 for free-falling liquids and powders) and leakpath factors from Refereace 27 (5E-03 for a $0.3 \mathrm{~g}$ earthquake), given that less than $10 \%$ of the maximum permissible facility inventory besed on NCSS limits is in-process, non-metal material. The result from the SAR (meen inventory) was an airborne release of 5E-3 curies, with a dose to the maximally exposed orisive individual of 7.6E-2 rurem, based on ICRP 2 values. The same accident, factored up to sccount for ICRP 30 dose values, would be 7 times greater in consequence. or 5.3E-1 mrem. Converting from a stack release, as andyzed in the SAR, to the more conservative ground release, the consequence would be 2.1 times greater, or $1.1 \mathrm{mrem}$. USQ screening/evaluation USQD-FBL-93-0458 documents this latter inadequacy in the SAR.

To model the bounding consequence of a DBE, the conservative assumption of the maximum allowable facility inventory based on the NCSS was used, and the release was analyzed using the updated AXAIR89Q dose code. The result was an unfiltered ground level airborne release of 0.310 curies, with a dose to the maximally exposed offsite individual of 42 mrem (ICRP 30). Co-located workers 640 metcrs from the stack, using 
WSAC-RP.90-11029fRev. 0. P200 46

$50 \%$ meteorology, could expect a dose of about 343 mrem (ICRP 30). This is conservative not only in the inventory assumptions, but also in the assumed release time of two hours.

Earthquakes of less intensity than $0.2 \mathrm{~g}$ could cause the ventilation stack liner to fail and possibly block the ventilation exhaust path. In the event of stack liner collapse, ventilation system interlocks (backed up by manual intervention) will stop the supply fans and prevent pressurization of the facility. Therefore, the result of an earthquake of intensity less than the DBE will be ventilation failure with possible facility air reversals. The impact of air reversals has already been examined in the SAR, whiere they are considered very low energy events whose consequences are contained within the facilities. These consequences could include building contamination, worker contamination, and worker assimilation. As a part of a USQ screening/evaluation for stack liner failure, the risk of other accidents during an earthquake of less intensity than the DBE wrs examined for the.F and $\mathrm{H}$ Canyon buildings. Based on the analysis shown in Reference 25, the additional risk of an accident capable of pressurizing FB-Line (a medium energetic event) occurring simultancously with a stack liner failure is $1.3 \mathrm{E}-4$ mrem/yr to the maximally exposed off site individual or an increase of about $5.2 \%$ in the risk due to medium energetic events. Since the SAR shows the risk due to medium energetic events to be $44.7 \%$ of the tool facility riste, this represents an increase in total facility risk of about $2.3 \%$.

\subsection{Earthquake Induced Nuclear Criticality}

A seismically induced criticality is not directly analyzed in the SAR. The most likely location for such an event to occur is in the vaults. The frequency of an earthquake indiced criticality is estimated to be 2.0E-04 per year, which is less than the process induced criticality frequency of $5.9 \mathrm{E}-04$ per year. This is bused on the frequency of an earthquake "of-0.1g intensity for the SRS area of 2.0 E-03 per year (oace every 500 years) and an estimated conditional probability of 0.1 (Reference 12) that the material in the racks will form a critical mass. WSRC commits to complete detailed analyses of the vault storage racks and provide a schedule for completion of any corrective actions necessary to meet these assumptions prior to declaration of readiness for restart. (C)

\subsubsection{Lor Energetic Events}

Altho!gh not a dominant accident scenario, low energetic events are discussed here because the bounding accident for the high frequency category is a low energetic event. A low energetic event is defined in the SAR as one which may cause penetration of the primary containment barrier, and occur at a frequency of several times per year. The low energetic events analyzed in the SAR are:

Traosfer Error -

Overflow -

Chemical Addition Error - intentional movecont of material to an unintended location, premature movement, or excessive moverment where potential for chemical reaction is unlikely excecting the capacity of a vessel

transfer of incorrect or unkmown material or quantity into a bown vessel, or addition of an undesired quantity of material 
Spill -

Leaks -

Sparge Failure -

Siphoning -

Coil or Tube Failure -

Pluggage -

Corrosion -

Over pressure - overturning or dropping of a vessel or container, liquid loss due to loose connections, liquid draining from a fitting that has been deliberately disconnected. or material seeping beneath a cabinet panel

loss of material from primary containment

failure to mix or purge a vessel

transfer of material to an unintended location due to difference in elevation

loss of integrity of primary contsinment through the heating or cooling system

forcign solid material deposits that restrict or halt fluid flow

loss of or decrease in integrity of primary : containment

unplanned addition of energy to a system beyond normal

The consequence analysis in the SAR conservatively took no credit for operator response, redundant process controls, or the HEPA filtration within the facility, with the toral release

" fraction released directly. to the sand filter.

The release percentage for a low energetic event, $0.001 \%$, (Reference 11) was applied to the typical batch size for one vessel. Using a sand filter efficiency of $99.51 \%$, the result was a release of 8.3E-5 curies, with a dose to the maximally exposed offsite individual of 1.3E-3 mrem (ICRP 2 values). The same accident, factored up to account for ICRP 30 dose values, would be 7 times greater in consequence, or 9.1E-3 mrem.

In order to provide a bounding case for an accident with high frequency, the same release percentage was applied to the maximum batch size permissible by NCSS in each process area, assuming typical weapons grade isotopics. The releases were analyzec using wive updated AXAIR89Q dose code. The resulting worst case was a release from the vaults due to a single can overpressure. A subsequent analysis was then performed (Reference 20) using maximum batch size and the worst case isotopic fraction for material stored in the vaults. The result was 2 release of $4.04 \mathrm{E}-02$ curies, with a dose to the maximally exposed offsite individual of 5.93 mrem (ICRP 30). Co-located workers 640 meters from the stack, using 50\% meteorology, could expect a dose of about 7.84 mrem (ICRP 30). 
Table 8.F

WSRC-RP-93-1102,Rev. 0

Summary Table of OSR/TS/SRS Documentation for FB-Line SAR and PHA Accidents

D.

Scenario

Ion Exchange Column Explosion

(Scenario Class I with respect to Facility Worker only)

\section{Preventors}

1
1

\section{Mitigntors}

SAR Requirements None

\section{OSR None} 4888 Semtion 32.2.1 2) The design of the cation exchange columas piping keeps the resin in these columns covered with solution at all times,

7 ) The column is equipped with a vent line

TS None without valves or restrictions. Section 3.2.22 2) The design of the anion exchangeociumn piping keeps the resin in these colvernins covered with solution at all times, 2) The column is also equippod with a vent line to
without valves or restrictions, 3$)$ To noeclude the The column is also oquippod with a vent line the
without valves or restrictions, 31 To noeclude the The column is also oquippod with a vent line to
without valves or restrictions, 31 To nreclude the initiate a resin explosion the column is maintained at a temperanure less than 60 degrees

Safety Related Systems

Brocedure Manual S1-1-1, Item 2.0.1. FB-Line

Configuration Control and Safety-Related Systems

$C, 4)$ Resin degradation as a result of radiation is

\section{Deaign Features}

- Room Exhaust Subsystem

Ars

- Cabinet Exhaust Subsystem \#a

Process Enclosures 10 limited by keeping the resin exposure level to less than $1 E+8 R, 5)$ Used resin, when it is to be discanded, is trea din such a manner that the - nitrate form is converted to the sulfate form.

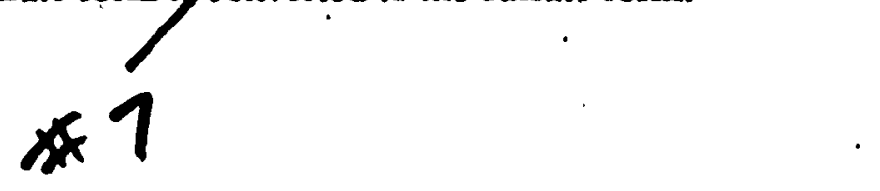


Table 8.F (continued)

WSRC-RP.93-1102, Rev. 0

Summary Table of OSR/TS/SRS Documentation for FB-Line SAR and PHA Accidents

Scenario

Ion Exchange Column Explosion

(Continued)

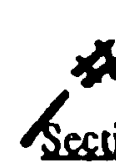

\section{Preventors}

Section 6.3.1 1) Use only the hydrogen form of strong acid cation exchange resins that have been qualified by laboratory tests of thermal stability and process compatibility, 2) tinil the maximum allowable column operating temperature to 60 degrees C, 3)-opectily service limits on radiation and/or chemical degradation times to permit removal of resins from service before they become hazandous under the allowed processing conditions, 4) Desebliah-tima limits on flow intemuption when using strong nitric acid in contact with resin to prevent resin from becoming hazardous, 5) Li.cit th a twactumum 5 allowable concentration of nifric acid to 9 molar, 6) No chemicals that produce explosive gas mixtures or compounds are cambined.

OSR DPW-85-101. Bey. 2,

7 1.2.2.C Limiting Control Settings for Ion Exchange Operations

- 2.2. L LCO requiring Ion Exchange Column Temperature Instruments

9 3.1.C.1 Surveillance Requirement for Ion

1 Exchange Column Instruments

\section{Mitigntors}


WSRC-RP-93-1102/Rev. 0

Table 8.F (continued)

Summary Table of OSR/TS/SRS Documentation for FB-Line SAR and PHA Accidents

Scenario

Ion Exchange Column

Axplosion

(Continued)

\section{Preventors}

TS

DPSTS-221-21.03: "Cation Exchange Coupling"

1 - C.lc Reain openting temperature

2. C.6n Pu clutriant $\mathrm{HNO}_{3}$ concentuation limits DPSTS-221-42.06: "Recovery Anion Exchange"

3. Cl1.b Resin oparating temperature

4 - Sulc Resin columns must be operated in a flooded condition

5 - Cld Concentration of nitric acid in contact with resin

Safety Related System:

Procedure Mnnunl S1-1-1. Jiem 2.01: FB-Line

Configuration Control and Safety-Related

Systéms

- Anion and Cation Temperature

6 Instruments

Administrative Controls Periodically flow

7 liquid through columns while facility is in standby to ensure resin remains wetted. This is required only if resin is loaded in column.

\& Visual sump inspections to detect potential leaks.

4 Change out the resin after a cumulative exposure of $1 E+8 \mathrm{rad}$ (anion), and $1 \mathrm{E}+\mathrm{rad}$ (cation).

Columns are not left in a lok ted state for an extended period.
Mitigators 
Table 8.F (continued)

WSRC-RP-93-1102,Rev. 0

Summary Table of OSRTSS/SRS Documentation for FB-Line SAR and PHA Accidents

Scenario

Single Level

Propapated Fire (Scenario Class II with respect to Co-Located Worker and Public)

\section{Preventors}

i
Mitigntors

SAR Requirements DPSTSA-200-10.Supp 2 SAR Requirements DPSTSA-200-10. Supp 9, 4/88 $4 / 88$ Anopendix D. Sections 3.4 and 4.3 Fire detoction is the first step in the fire protection and is socomplished by fire watch surveillance and normal operations stuff present. Section 5.3.2.2 The principal barrier to radiaactivity 3 release to the environment via the process enclosure ventilation system and the room ventilation systern is the sand filter servicing 5th and 6th level exhausts.

\section{OSR None}

TS None

Safety Related Systems None

\section{Administrative Controls}

Until computer modeling of fire effects on vault

7 contents and any resultant upgrades are

complete, transient combustibles will be restricted in rooms adjacent to the vaults.
OSR DPW-85-101. Rev. 2. (8/24)

4. 3... 1 Surveillance Requirements for Sand Filter and if HEPA Filters

$\therefore$ TS None

\section{Safety Related Systems}

Procedure Manual S1-1-1, Item 2,0., FB-Line Configuration Control and Safety-Related Systems

- Building Walls

6 - Duct to Sand Filter

7 - Sand Filters

8. Cabinet Exhaust

9. Room Exhaust

Administrative Controls

10 Restrict combustibles from the vicinity of NIM units.

\section{Design Features}

Process Enclosures 
Scenario

Insdyentent Criticality (Scenario Class I with respect to Facility Worker only)

\section{Preventors}

SAR Requirements DPSTSA-200-10. Supp 9 4/88. Section 3.2.2.1 The four cation exchange

1 column of eight cylindrical segments, the

Product Run Tanks, the Product Hold Tanks, and Sump Receipe Tank, are constructed to be geometrically favorable vessels for the concentrations handled.

Section 3.2.2.2 The accumulation of $\mathrm{Pu}$ precipitutes on the walls of the precipitator could'

2 conceivably result in a $\mathrm{Pu}$ accumulation in excess of the $8 \mathrm{~kg}$ Pu batch limit. A monitor: alerts operutors to the ext it of the buildup, then flushes are performed to remove it. Secrion 322.6 The racks :re constructed to

physically space only one can per rack position

3 physically space only one can per rack position, TS DPSTS-NMM-85 requirements. Secion $3,2.221$ ) Solution overflowing from a

4 tank or leaking from a process line collects in geometrically favorable sumps provided beneath each tank 2) The solution in A-6 must be less than $17 \mathrm{~d} / \mathrm{Pu}$ prior to transfer to canyon tanks.

5 . This is because the solution is transferred using 3:1 eductor 3) The transfer line contains a

6 siphort oreak which is necessary to prevent tank if the eductor motive solution (dilute nitric acid) should stop after the transfer is started.

7 Section 3.2.3.1 The cation exchange column and cation exchange are limitod to geometrically favorable configuration for criticality safety.

\section{Mitigators}

SAR Requirements DPSTSA-200-10. Supp 9.4/88 Section 4.9.6 NIMs are provided at strategic locations throughout 200-Area facilities. These monitors are provided wherever fissionable materials are stored, or processed in sufficient quantity for a potential critical configuration. The monitors alarm to warn personnel to move to certain locations, along with previously established well marked routes.

OSR DPYY-85-101. Rey, 2. (8/24)

2.1.C LCOs requiring NIM system and that it be operational during fissile material handling

$103.1 . \mathrm{C} .1$ Surveillance Requirement for NIMs

\section{Sofety Related Systems}

Procedure Manual S1-1-1.Jtem 2.0.1; FB-Line

Configuration Control and Safety-Related Systems

$$
\text { 12. NIMs }
$$

a Administrative Controls

Annual NDM Response Training

NIMs monitoring a potential incident location are bypassed to perform authorized work per approved work package or workbook. Prior to bypassing of NIMs, operations in that location are brought to a safe configuration per facility procedures.

Design Features

Process Enclosures 
Table 8.F (continued)

WSRC-RP-93-1102,Rev. 0

Summary Table of OSR/TS/SRS Documentation for FB-Line SAR and PHA Accidents

Scenario

Inadvertent Criticality

(Continued)

\section{Preventors}

Section 3.2,3,2 The hardwired neutron monitors will result in termination of the $\mathrm{Pu}$ feed to the

I first and cecond stage presipitators upon a high neutron count

Section 3.3.5.1. Process vissels for Pu solution of concentrations greater than $6.75 \mathrm{~g} /$ are geometrically favorable to design for nuclear

2 criticality control. Typically, these vessels have a maximum width of 4.0 in. For metal vessels, this width is maintrined by property spaced stayi bolts. Plastic vessels are housed in a metal frame to prevent the vessel from bulging. Collection sumps are built into the bottom (or lower level) of all process enclosures. All process vessel are suspended above these collection sumps. The dimensions of each sump for highly concentrated solutions are, in effect, greater than the maximum volume of the vessel(s) served by that sump. Therefore, should a process vessel lose its integrity, the solution dimensions would be maintained geometrically favorable for nuclear safety. (See Design Features for exceptions.)
Mitigators 
able 8.F (continued)

WSRC-RP-93-1102,Rev. 0

Summary Table of OSR/TS/SRS Documentation for FB-Line SAR and PHA Accidents

Scenario

\section{Preventors}

Section 5.6.4.21) In situations where

concentrated Pus lutions are transferred to vessels where the concentration limit for vessels with unrestricted geometry applies, written procedures act to ensure that adequate controls are in place to ensure safety, 2) Siorage of $\mathrm{Pu}$ in

2 the vaults and movement of Pu within FB-Line are by approved operating procedure to avoid accumulation of Pu in excess of sefe mass limits and violation of critically safe geometry.

3 Section 6.2.1 Before geometrically favorable vessels are placed in service, vessels must be measured and the dimensions independently verified using approvod.nuclear safety measurement procedures and measuring instruments calibrated to NBS standards.

i. Section 6.3.1 1) The limits for Pu 239 concentration in an ungeometrically favorable

5 vessel is $6.75 \mathrm{~g} /, 2$ ) Colloction of fissile process solution leaks in containers is prohibited (deviations require use of geometrically favorable containers per special procedure

6 approved by the Nuclear Safety Group), 3)Prior to removing cabinet panels for work inside the . cabinet, confirm and verify (dual and independent) that all nuclear safety control limits are met and proper panel (dual and independent)

7 is being removed 4) Routinely; survey (flush, monitor or visually inspect) suinps, seal pots, and other designated process iszations for accumulation of potential Pu-bearing solids.
Mitigators

\section{1}


Summary Table of OSRTS/SRS Documentation for FB-Line SAR and PHA Accidents

\section{Scenario}

Inadvertent Crivicality (Continued)

\section{Preventors}

I Section 6.3.21) Monitor and verify Pu inventory in precipitumen prior to starting each

2 procipitution, 2) Routinely chock and calibrate safety-relauod neutron monitors with a neutron source and verify neutron monitors (M-2, M-3)

3 will alamm if specified set points are exceedod 3)

3 Verify and document that the dimensions and tolenances for new tunks and equipment to be

4 installed are in specifications, 4) Prior to

removing cabinet panels for work inside the cabinet, confirm and verify (dual, independent) : that all nuclear safety control limits are met and proper panel (dual, independent) is being removed.

5 Section 6.3.41) Before replacing resin in the 5 anion resin cotumns, $A-4 \mathrm{~A} / \mathrm{B}$, elute the columns as directed in approved procedures to remove residual Pu. Verify and confirm actions tuken,

C 2) Prior to removing cabinet panels for work inside the cabinet, confirm 1-1d verify (dual and independent) that all nuclea: safety control limits are met and proper panel (dial and independent)

7 is being removed. 3) Transfer eluting solution from A-6 to canyon tanks 182 and 10.3 in the hot canyon as specified in approvod operating procedures to keep Pu concentration and scid concentration within specified Nuclear

8 Criticality Safety limits, 4) Operate A-6 tank as specified in approved operating procedures to prevent accidental transfer of $A-6$ tank contents to canyon tanks. Siphon break line should be open (not blanked) to prevent siphoning of A-6 contents to canyon tanks.

\section{Mitigators \\ 1}




\section{Scenario}

Mitigators

In edvertent Criticality 6.3 .6 Control neutron shielding, filter tube (Continued)

spacing, and Pu mass limits for the solution

trangfer filcers, ir drying filter and vessel vent filter as specified in the approved Nuclear Safety Control openting procedures.

OSR DPW-85-101. ReY 2. (8024)

$21.1 \mathrm{C} .1 .6$ Safety Limits

1.2.1.CLimiting Control Settings which limit composition and configuration of fissile components to prevent formation of a critical array.

4 1.2.6. .4 Limiting Control Setting for concentration of hydrogen.

2 2. C LCO requiring Gamma Pulse Height

Analyzer Instrument (Sample PHA, Segmented Gamma Scanner, and Portable Waste PHA) and Hydrogen Dilution Controls

3. C. I Surveillance Requirement for

6 Precipitator Neutron Monitors, Sample PHA, Segmented Gamma Scanner, and Portable Waste PHA

7 TS DPSTS-221-0.09 and DPSTS-221-0.02 SuD

7 All NCSS except NCSS 10, 11, 20, and 24

6 TA WSRC-TA-91-00002-12-Extension Rey. 2) 
Scenario

Inadventent Criticality (Continued)

\section{Preventors}

Mitigators

\section{Safety Relnted Systems}

Procedure Mnnual S1-1-1. Jlem 2.0.1: FB-Line

Configuntion Control and Safety-Related

System

1. Sample Assay Equipment

2. Waste Assay Equipment

- Precipitator Neutron Monitors

4 - Process Vessel and Sump Geometry

- Vault Stonge Location Geometry

- Nuclear Safety Blanks

- Recovery Product Tank (A6) Eductor

S. Funishing Balance

- Dissolver Hydrogen Dilution Control Rotameters

10. Hydrogen Dilution Vessel Vent Purge System

11 - Hydrogen Dilution Vessel Pneumatic Purge System

12 Design Features The sumps for the New ST

Vacuum System Cabinet and the C\&D

13 Precipitator Cabinets have overflows.

\section{Administrative Controls}

14 Annual Nuclear Criticality Safety Training

15 Nuclear criticality safety samples are analyzed Wituin the FB-Line facility or by the analytical laboratory.

16 Dual signatures are required for vault procedure steps that verify safe Pu mass limits or critically safe geometry configuration when storing and handling Pu material.

17 Monitoring to prevent excessive accumulation of $P u$ in ventilation ducts.

Procedures are in place to maintain hydrogen concentration less than 25\% of the LFL. 


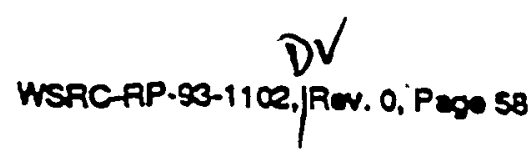

\subsubsection{Non-radiological Evaluation}

A review was also made of the facility's chemical hazards. The SAR, Section 5.4.7, addresses chemical hazards in FB-Line, with the conclusion that the associated risk is acceptable. Based upon operating experience which includes greater than 30 years without a significant chemical release, continued operation is judged to be acceptable. In addition, Emergency Action Levels have been established according to Procedure Manual 60 and documented in EPIP EPIP-6Q-FBL-PSF-001. This BIO will be revised within 6 months of approval, to provide a complete analysis of the environmental effect of hazards and an evaluation of chemical hazards (C). Chemicals used as liquids in the FB-Line processes have been reviewed to determine if any are present in sufficient quantity to be of a regulatory concern. There are no chemicals in FB-Line in excess of the Threshold Quantities (TQ) per OSHA PSM Rule 29CFR1910.119.

\subsection{Farmer Plots}

The public and co-located risk of the bounding (maximum source term) accidents in FBLine are shown in Table 8G and the Farmer Plots in Figures 1 and 2. These values are included only to allow comparison of the bounding accident ristes with WSRC Risk Acceptance Guidelines. Defense-in-depth for FB-Line is documented in this BIO' using Table 8.F, Summary Table of OSR/TS/SRS Documentation for FB-Line SAR and PHA Accidents.

Table 8.G

Summary Table of Risk for FB-Line Bounding Accidents

\begin{tabular}{|c|c|c|c|c|c|}
\hline ACCDENT & $\begin{array}{l}\text { FREQUENCY, } \\
\text { per yea }\end{array}$ & $\begin{array}{l}\text { COLOCATED } \\
\text { MAXIMUM } \\
\text { INDIVIDUAL } \\
\text { DOSE, rem } \\
\end{array}$ & $\begin{array}{l}\text { CO-LOCATED } \\
\text { MAXMMUM } \\
\text { DNDIVIDUAL } \\
\text { RISK, TembY }\end{array}$ & $\begin{array}{l}\text { OFFSITE } \\
\text { MAXIMUM } \\
\text { DNDIDUAL } \\
\text { DOSE Iem } \\
\end{array}$ & $\begin{array}{l}\text { OFFSIIE } \\
\text { MAXIMUM } \\
\text { DNDIDUUA } \\
\text { RISK, remfr }\end{array}$ \\
\hline Eanthque'ce & $2.0 \times 10^{-4}$ & $3.43 \times 10^{-1}$ & $6.9 \times 10^{-5}$ & $42 \times 10^{-2}$ & $8.4 \times 10^{-6}$ \\
\hline Criticality & $5.9 \times 10^{-4}$ & $2.6 \times 10^{-1}$ & $51.5 \times 10^{-4}$ & $7.0 \times 10^{-3}$ & $54.1 \times 10^{-6}$ \\
\hline Propagiced Fire & $1.7 \times 10^{-5}$ & $5.21 \times 10^{0}$ & $8.9 \times 10^{-5}$ & $3.95 \times 10^{0}$ & $6.7 \times 20^{-5}$ \\
\hline $\begin{array}{l}\text { Fourth Level } \\
\text { Fire }\end{array}$ & $1.7 \times 10^{-4}$ & $2.95 \times 10^{\circ}$ & $5.0 \times 10^{-4}$ & $2.23 \times 10^{0}$ & $3.8 \times 10^{-4}$ \\
\hline $\begin{array}{l}\text { Low Energecic } \\
\text { Event in Vell }\end{array}$ & $9.0 \times 10^{-2}$ & $7.84 \times 10^{-3}$ & $7.1 \times 10^{-4}$ & $5.93 \times 10^{-3}$ & $5.3 \times 10^{-4}$ \\
\hline
\end{tabular}


Figure 1

RISK OF FB-LINE - BOUNDING ACCIDENTS OFF-SITE

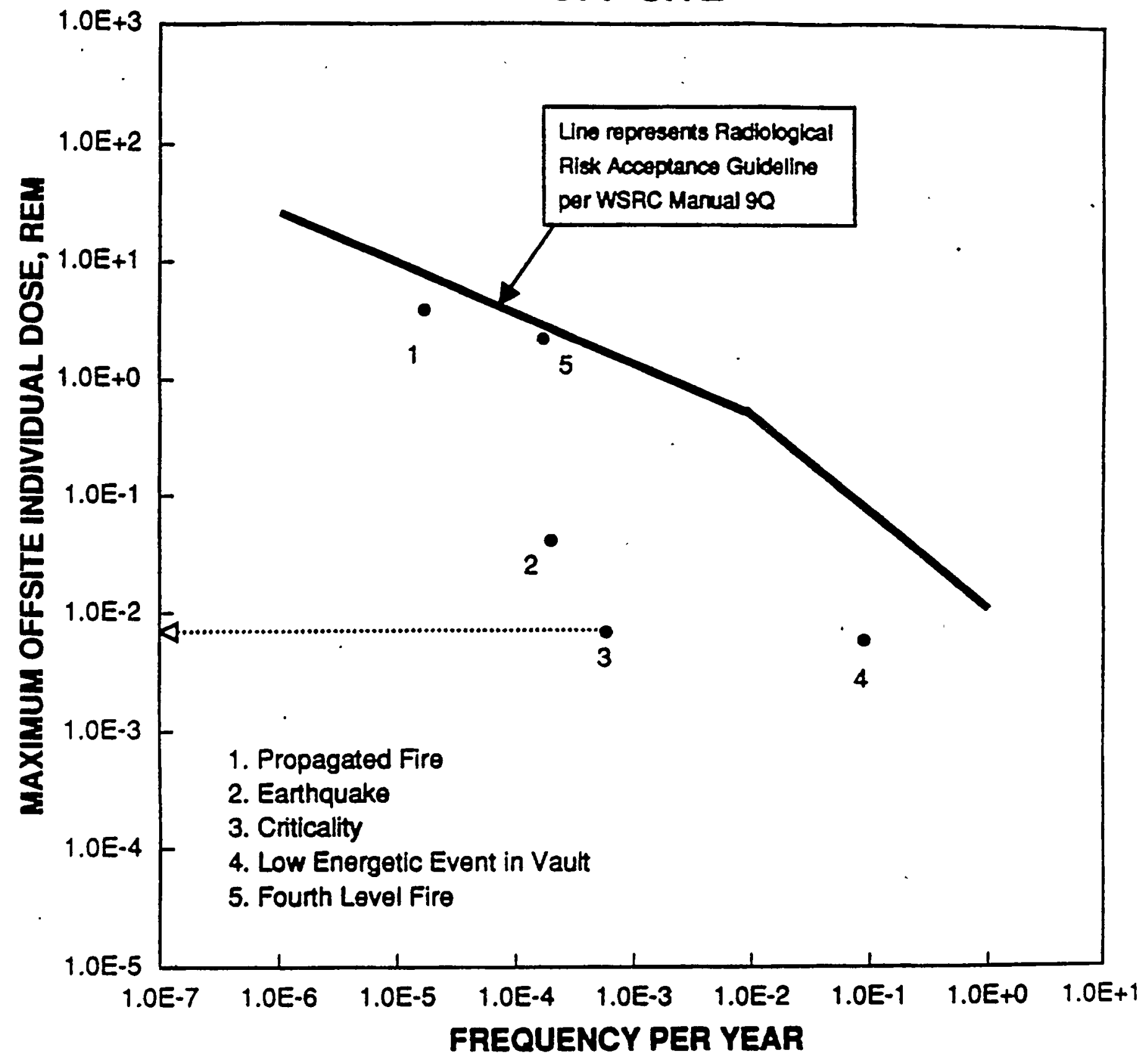


$D V$
WSAC-RP.93-1102,|Rov. 0, Page 60

Figure 2

\section{RISK OF FB-LINE - BOUNDING ACCIDENTS CO-LOCATED}

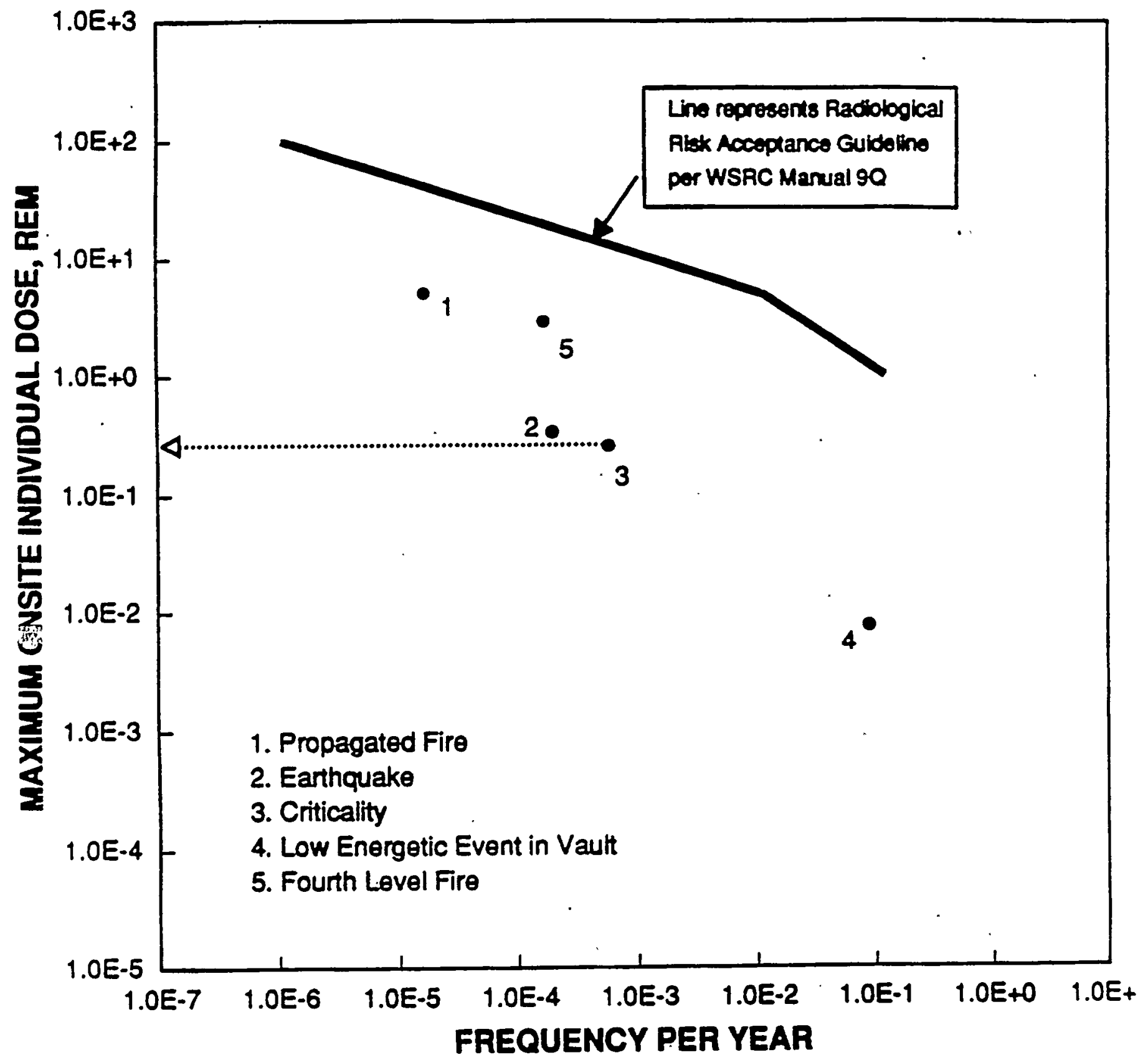

Unchastifed-Controlted-Nueteaf Informatiod

Seprember 23, 1994 


\subsection{Safety-Related Description Approach}

The accidents analyzed in the SAR were examined and the major features to detect, prevent, or mitigate the accidents were identified as Safety-Related systems. Safety-Related systems for FB-Line are addressed in Procedure Manual S1-1-1, Item 2.01, "FB-Line Configuration Control and Safety-Related Systems (U)", Rev. 1 (Draft). This procedure will be approved and issued before declaration of readiness for restart (C). It defines specific FB-Line systems and components as well as F-Area systems that can impact FB-Line operations. It describes the actions to be taken upon failure or unavailability of a Safety-Related system or component and the bases for the actions. It also describes the testing/surveillance requirements for FB-Line specific systems. Testing/surveillance requirements for F-Area systems related to FB-Line are documented in Standard Operating Procedure (SOP) 221-F/OF-F-51230, "F-Canyon/OFF/FA-Line Safety Related Systems". Both procedures include the criteria for selection of the Safety-Related systems and components. FB-Line systems are summarized in Table 8.H below.

Some systems are required for all operations within FB-Line, while others are required only for operation of specific processes. The Safety-Related systems for FB-Line are identified by unit operation in Table 8.I.

The schematics for selected Safety-Related systems and other support systems are presented in the PHA. 
Table 8.H

Safety-Related Systems and Components for FB-Line

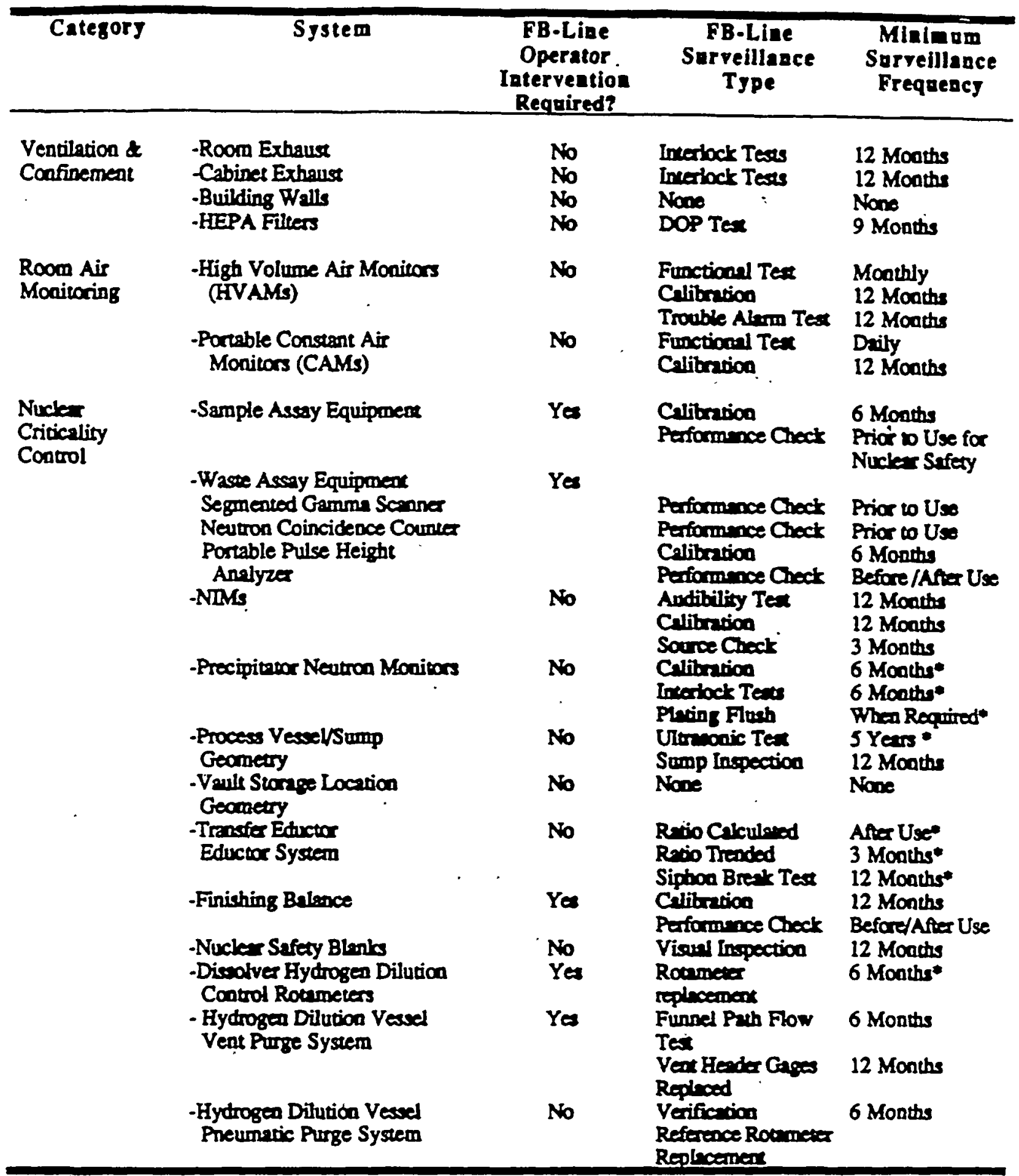

- During process operation 
Table 8.H (continued)

Safety-Related Systems and Components for FB-Line

\begin{tabular}{|c|c|c|c|c|}
\hline Category & System & $\begin{array}{c}\text { FB-Line } \\
\text { Operator } \\
\text { Intervention } \\
\text { Required? }\end{array}$ & $\begin{array}{c}\text { FB-Line } \\
\text { Surreillance } \\
\text { Type }\end{array}$ & $\begin{array}{l}\text { Mininam } \\
\text { Surveillance } \\
\text { Prequency }\end{array}$ \\
\hline $\begin{array}{l}\text { Sundby } \\
\text { Electrical Power }\end{array}$ & -FB-Line Diesel Generabas & No & 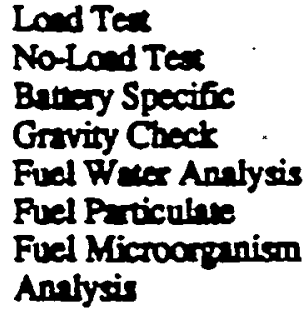 & $\begin{array}{l}12 \text { Months } \\
4 \text { Months } \\
3 \text { Months } \\
\\
\text { Monthly } \\
3 \text { Months } \\
12 \text { Moaths }\end{array}$ \\
\hline Process Hazeds & $\begin{array}{l}\text {-Ion Exchsnge Column } \\
\text { Temperenure Instrumentation }\end{array}$ & No & $\begin{array}{l}\text { Calibration } \\
\text { Incerioct Texs }\end{array}$ & $\begin{array}{l}12 \text { Moaths" } \\
18 \text { Moaths" }\end{array}$ \\
\hline $\begin{array}{l}\text { F-Area Common } \\
\text { Systems }\end{array}$ & 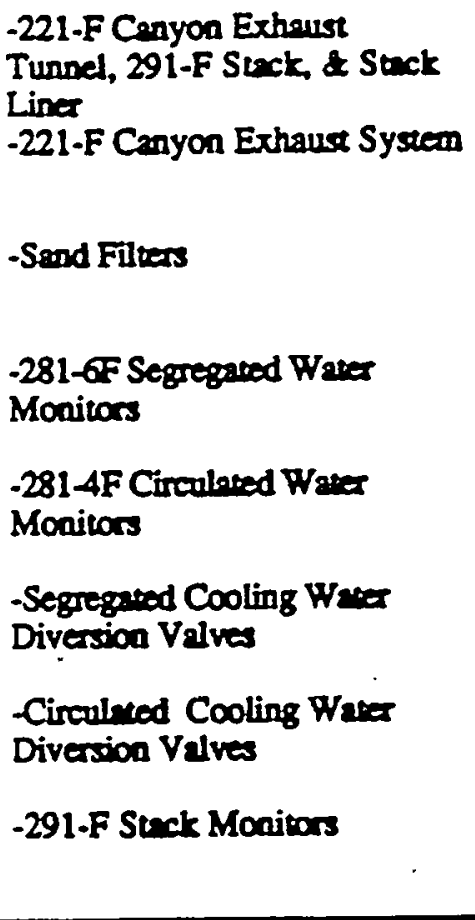 & No & 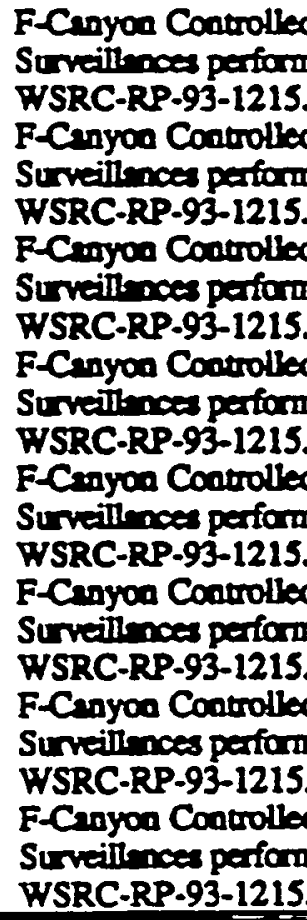 & 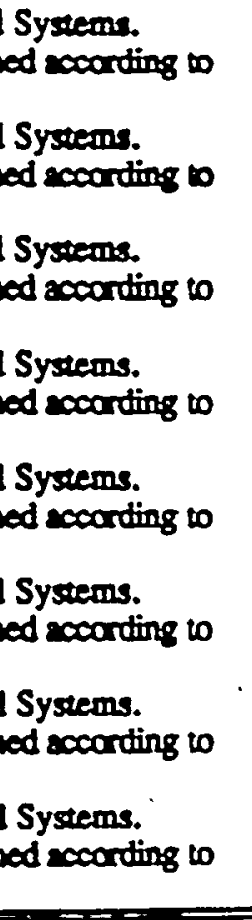 \\
\hline
\end{tabular}

\footnotetext{
During process operation
} 
DU
WSAC-RP-so-1100/, Rev. 0, Peop of

\section{Table 8.I}

\section{Safety-Related Systems Required for FB-Line Operations}

\begin{tabular}{|c|c|c|}
\hline Unit Operation & Required Safety-Related Components & -When Required: \\
\hline \multirow[t]{2}{*}{ Facility } & 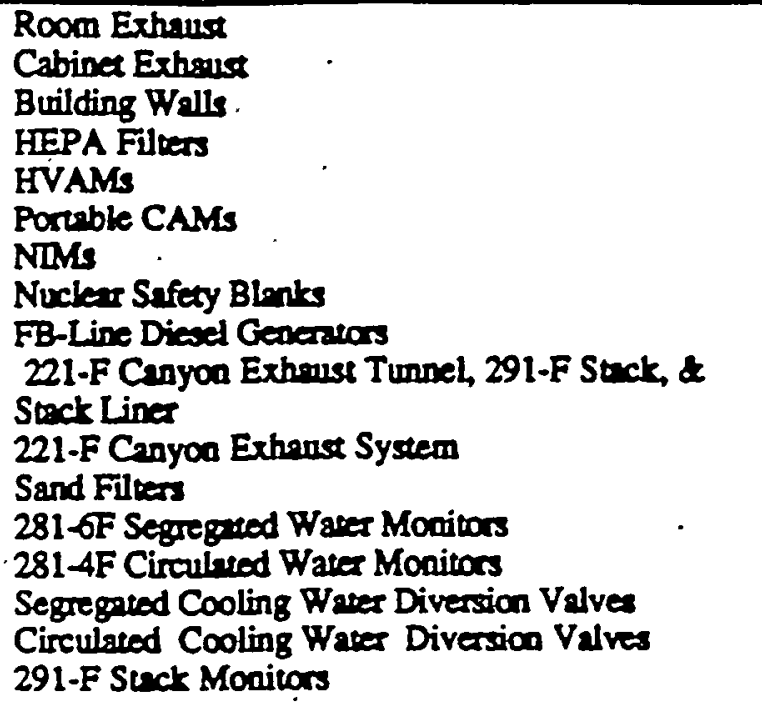 & All times \\
\hline & $\begin{array}{l}\text { Veasel/Sump Geometry } \\
\text { Hydrogen Dilution Vessel Vent Purge System } \\
\text { Hydrogen Dilution Vessel Preumntic Purge System }\end{array}$ & $\begin{array}{l}\text { Whea mocived vessels conthin fiscile } \\
\text { merial }\end{array}$ \\
\hline $\begin{array}{l}\text { Cation } \\
\text { Exchenge }\end{array}$ & $\begin{array}{l}\text { Ion Exchange Column Temperaure } \\
\text { Instrumentosion }\end{array}$ & $\begin{array}{l}\text { When ficsile merisl is being fed to the } \\
\text { cation exchenge columns }\end{array}$ \\
\hline $\begin{array}{l}\text { Precipiurion } \\
\text { and Filuretion }\end{array}$ & Procipituer Neutron Moniror & Durins precipiturer operution \\
\hline $\begin{array}{l}\text { Mechanical } \\
\text { Line }\end{array}$ & Finishing Balance & $\begin{array}{l}\text { Prior io moving fissile muterial out of the } \\
\text { finishing cabinet }\end{array}$ \\
\hline \multirow[t]{4}{*}{ Recovery } & Sample Aseny Equipment & Prior vo tranefering product to F-Canyon \\
\hline & Transfer Eductor System & $\begin{array}{l}\text { When trandering from tank } A-6 \text { to F- } \\
\text { Canyon }\end{array}$ \\
\hline & Dissolver Hydrogen Dilution Control Roumeters & $\begin{array}{l}\text { During discolution of material that } \\
\text { generines hydrogea }\end{array}$ \\
\hline & $\begin{array}{l}\text { Ion Exchenge Column Temperature } \\
\text { Instrumention }\end{array}$ & $\begin{array}{l}\text { When arion exchange columns contain } \\
\text { resion }\end{array}$ \\
\hline $\begin{array}{l}\text { Waste Handling } \\
\text { Operations }\end{array}$ & Waste Asery Equipment & $\begin{array}{l}\text { Prior to removing TRU waste from the } \\
\text { facility }\end{array}$ \\
\hline Vaults & Vault Storige Location Geometry & When the veults cononin fissile material \\
\hline
\end{tabular}

* Compensatary measures per S1-1-1, Item 2.01, shall be in plece whea composent is not operable wbea required 
$D V$
WsACAP.03-110e/Anow. 0, Pepo 65

\subsection{CONCLUSION}

The safety analysis of the FB-Line Facility indicates that the operation of FB-Line to support the current mission does not present undue risk to the facility and co-located workers, general public, or the environment. This is based on the results of the hazard and accident analysis; the verification of the adequacy of the safety envelope by identification of controls, procedures and/or preventive and mitigative feaures against release of hazardous materials; and the implementation of ageressive safety management programs that ensure facility safety by adhering to principles of sound safety engineering and management practices. This conclusion is further supported by the existence of corrective and compensatory measures to reduce the frequencies and/or consequences of Class I accident scenarios.

\subsection{REFERENCES}

1. DOE Standard, Hazard Categorization and Accident Analysis Technioues for Compliance with DOE Order 548023. Nuclear Safery Analysis Reports, DOE-STD-1027- . 92, U. S. Departoent of Energy, Washington, D. C., December 1992.

2. J. W. McClard to R. L. McQuinn, EB-Line Exhaust Duct System Monitoring Propram UU), NMP-SBT-0102, May 20, 1992.

3. Memorandum from E. N. Moore to A. S. Messick, "Upgrade Review FB-Line Facility," 1980.

4. Fire Hazards Analysis for Building 221-EB-Line IU M-FHA-F-00022, Rev. 4, February 14, 1994.

5. Configuration Management Program Plan for EB-Line Facility WSRC-RP-94-568, June 28, 1994.

6. M. L. Kellogg to P. L. Fisk, EB-Line Maximum Inventory (U), NMP-SDG-93043, Rev. 1, June 21, 1993.

7. Handbook of Chemistry and Physics, 47th Edition, The Chemical Rubber Co., 1966.

8. M. E. DelGenio to J. M. Low, EB-Line Vault Inventory CU, SRT-DCA-94-0014, January 21, 1994.

9. Nonreactor Nuclear Facjilities Safety Analysis Repon Fonmat and Content Guide, SROM 5480.5-1, U. S. Deparment of Energy, Savannah River Operations, Aiken, SC, February 1989.

10. DOE-STD-3011-94, Guidance for Preparation of DOE 5480.22 (TSR) and DOE5480.23 (SAR) Implementation Plans, August 1994.

11. Stoddard, D. H., Guides for Estimating Consequences in 200 Area Systems and Safety Analyses, DPST-82-789, August 1982.

12. Systems Analysis - 200 Area Sayannah River Plant. EB-Line Operations, Internal Report DPSTSY-200-10, Rev. 1, October 1985. 


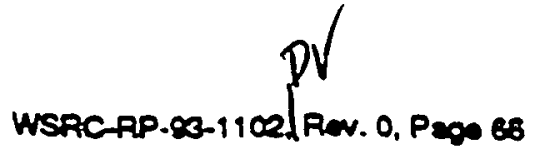

13. W. S. Durant and D. H. Stoddard to E. W. Holtzscheiter, Revised Eault Tree and Consequence Analysis of FB-Line Based en 1986 Administrarive Control and Equipment Upprades, DPST-86-558, July 18, 1986.

14. H. S. Smiley, Ereouency Analysis for Criticality due to Hyotrogen Deflaprarion in EBLine Yessels OD, WSRC-TR-94-0192 (Draft), June 1994.

15. S. F. Walters to C. L. Martin, EBL NTM Eyacuation Plan to Validate SAR Assumptions Results [U], NMP-SBO-91-0724, December 12, 1991.

16. T. P. McLaughlin, LANL, Reviexy of Sayannah River Site (SRS) EB-Line Safety Analysis Report (SAR) for Criticality Accident Analyses. Assumptions, and Consequences, HS-6-92-214, October 30, 1992.

17. R. C. Grim, Parsons Main, to D. E. Berning, EB-Line Eire Spread Eyaluation for Yaults 309 and 410A TI. EPD-CTM-94-569, June 23, 1994.

18. D. S. Cramer and C. L. Sossman, Impact of Hot Electrical Shorts in F-Canyon Equinment [ת, WSRC-RP-94-637 (Draft), August 1994.

19. P. L. Fisk to T. G. Campbell, Review of the Erequency of a Postulated Earthouake Induced Major Fire in F-Canyon EB-Line UD, EPD-RAG-940010, June 28, 1994.

20. Soecification No, 7096. Stouctural Specification for Building Code Requirements for Sayannah Rivet Site. Aiken. South Caroling, Engineering Departorent, E. I DuPont De Nemours \& Co. Inc.

21. Seismic Evaluation of Building 221-E Section 2 and JB-Line Penthouse Addition at the Sayannah River Plant Aiken.S.C. EDAC-253-070.03, September 1981.

22. Phase I - Eeasibility Study of Building 221-F Section 6 with JB-Line Penthouse Addition Using Blume Seismic Criteria al the Savannah Biver Plant. Aiksn. S.C. EDAC253-110.02, April 1983.

23. Phase III Seismic Analysis of Building 221-E Sections 5 Through 8 with JB-Line Penthouse Addition Using Blume Sejisuic Criteria it the Saysanah River Plant Aiken.S. C. EDAC-253-112.02, July 1983.

24. Baldwin, G. R. Evaluation of the F-Area Separation Building Yentilation System Stuctures, Internal Repor EPD-SE-91-0235:63, October 23, 1991.

25. P. L. Fisk to Distribution, Eyaluation of the Risks Reganding Exhaust Stack Liner Collapse After 0.04 \& Earthquake Ud, Internal Report SRL-0AG-92-0041, Revision 3, April 30, 1992.

26. DelGenio, M. E. to H. S. Smiley, Worst Case Consequence for EB-Line Low Energetic Event. (U) EPD-CAT-94-0038, August 16, 1994.

27. A. Kolaczkowski, et al., DP Safery Suryey. HB-Line and EB-Line. Sayannah River Site, Draft, November 27, 1991. 


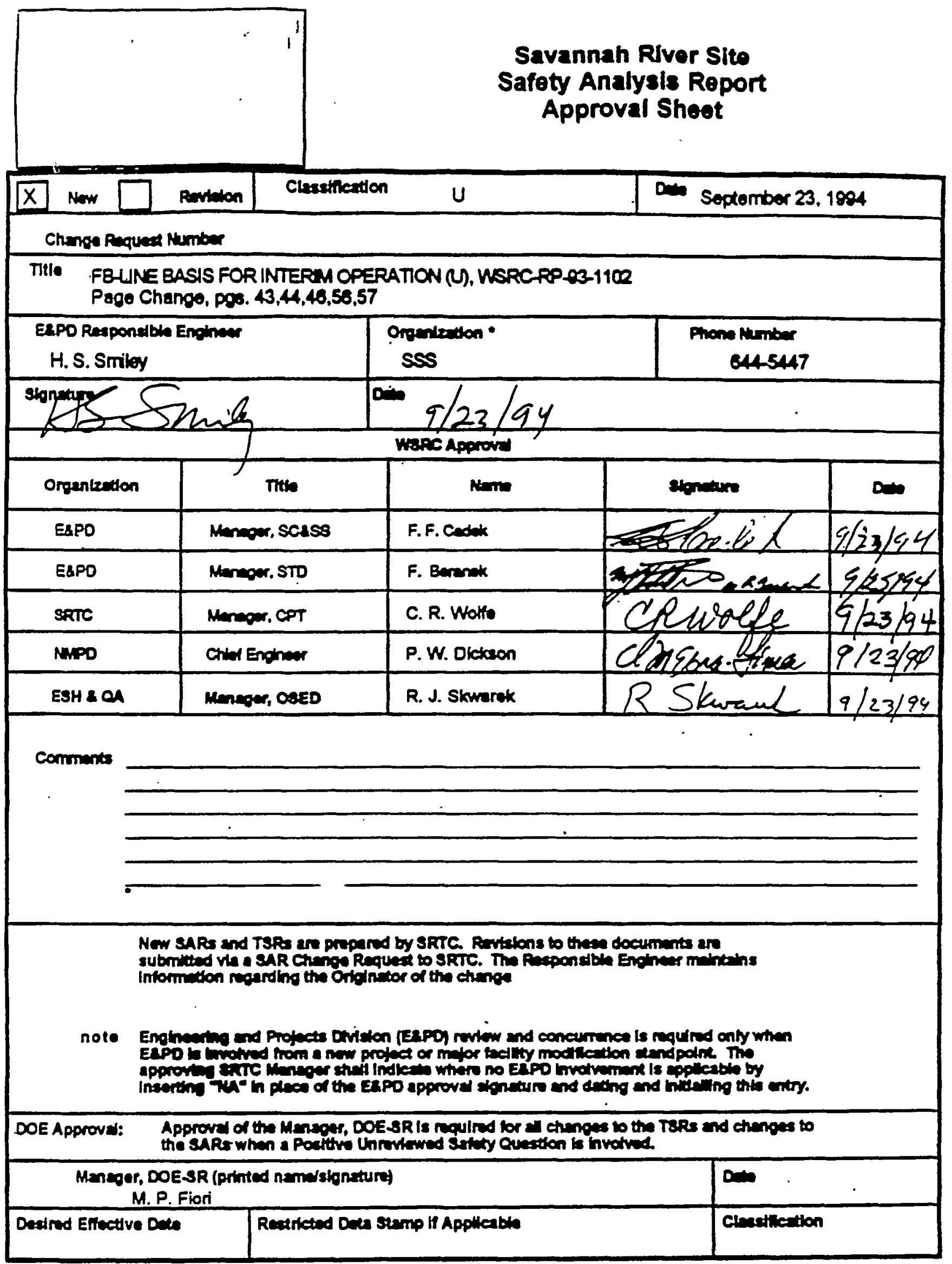

